\title{
Biozonation and biochronology of Miocene through Pleistocene calcareous nannofossils from low and middle latitudes
}

\author{
Jan Backman ${ }^{1}$, Isabella Raffi' ${ }^{2}$, Domenico Rio ${ }^{3}$, Eliana Fornaciari ${ }^{3}$, \\ and Heiko Pälike ${ }^{4}$
}

With 10 figures and 4 tables

\begin{abstract}
Calcareous nannofossils are widely used in Cenozoic marine biostratigraphy. At present, the two most widely used calcareous nannofossil biozonations were established approximately 40 years ago. These were derived from marine land sections and Deep Sea Drilling Project rotary cored sediments. Over nearly three decades, we have generated Miocene through Pleistocene calcareous nannofossil data from deep sea sediments in low and middle latitude regions. The sediments used here have been mostly recovered using the advanced piston coring technique, generating less core disturbance and complete recovery via multiple penetration of the sediment column at single sites. A consistent trait in our work on calcareous nannofossil biostratigraphy has been to use semi-quantiative methods in combination with short sample distances, close enough to capture the details of the abundance behaviour of individual calcareous nannofossil taxa. Such data represent the foundation of the new biozonation presented here, which still partly relies on the pioneering work presented by Erlend Martini and David Bukry about 40 years ago. A key aim here has been to employ a limited set of selected biohorizons for the purpose of establishing a relatively coarsely resolved and stable biozonation. We present 31 biozones using a new code system: CNM1-CNM20; Calcareous Nannofossil Miocene biozones 1 through 20. CNPL1-CNPL11; Calcareous Nannofossil Plio-Pleistocene biozones 1 through 11. As the new biozonation encompasses 23 million years, the average biozone resolution becomes 0.74 million years, ranging from 0.15 to 2.20 million years. A single biohorizon is used for the definition of each biozone boundary. Auxiliary markers are avoided, as well as subzones, in order to maintain stability to the new biozonation. Virtually every biozone holds one or several additional biohorizons. These, together with all biozone boundary markers, are assigned age estimates derived chiefly from astronomically tuned cyclostratigraphies.
\end{abstract}

Key words. calcareous nannofossils, biozonation, biochronology, Miocene-Pleistocene

\footnotetext{
Authors' addresses:

1 Department of Geological Sciences, Stockholm University, SE-10691 Stockholm, Sweden, E-Mail: backman@geo.su.se Corresponding author: Jan Backman, Phone +46-8-164720, Fax +46-8-6747897

2 Dipartimento di Ingegneria e Geologia (InGeo) - CeRSGeo, Università degli Studi “G.d'Annunzio" Chieti-Pescara, via dei Vestini 31, 66013 Chieti-Pescara, Italy, E-Mail: raffi@unich.it

3 Dipartimento di Geoscienze, Università degli Studi di Padova, via G. Gradenigo 6, 35131 Padova, Italy, E-Mail: domenico.rio@unipd.it, eliana.fornaciari@unipd.it

4 Center for Marine Environmental Sciences (MARUM), University of Bremen, D-28359 Bremen, Germany, E-Mail: hpaelike@marum.de
} 


\section{Introduction}

About 40 years ago, a series of calcareous nannofossil biostratigraphic zonations was established for various parts of the Cenozoic stratigraphic column (Hay et al. 1967, Gartner 1969, 1971, Bukry and Bramlette 1970, Martini 1969, 1970, Martini and Worsley 1970). These were all based on the study of marine land sections and/or rotary cored Deep Sea Drilling Project sediments, a drilling technique characterised by low recovery and disturbed cores (JOIDES Journal, June 1979; www.odplegacy.org). Biozonations for the entire Cenozoic were developed by Martini (1971) and Bukry $(1973,1975,1978)$. Martini introduced 25 Paleogene and 21 Neogene zones (NP/NN zones), whereas Okada and Bukry (1980) codified Bukry's 19 Paleogene and 15 Neogene zones (CP/CN zones). In addition, Okada and Bukry (1980) also codified 20 Paleogene and 24 Neogene subzones. These two zonal systems are still widely used, in spite of Bukry's (1973a) insightful comment that " ... the continuing recovery of deep-ocean sediment sections by the D/V Glomar Challenger at various latitudes will provide the material needed to thoroughly evaluate the stratigraphic and geographic ranges of coccolith species. This will permit more consistent zonation." Bukry's zonation was "not intended to be exhaustive but simply illustrates the basis of a low-latitude open-ocean coccolith zonation". He thus aimed to establish a general framework for relative dating of open ocean sediments rather than producing the highest possible resolution. This spirit is adopted here, together with the general aim to produce a "more consistent zonation".

Among us, a paper by Rio (1974) was the first in a still ongoing effort (Fornaciari et al. 2010, Agnini et al. 2011) to generate biostratigraphic data using Cenozoic calcareous nannofossils. Many biostratigraphic studies of Cenozoic calcareous nannofossils present data in the form of range charts, characterised by qualitative estimates of relative abundances of taxa in widely spaced samples. As discussed by Backman and Raffi (1997), it is difficult to judge the quality of individual biohorizons from qualitative presence-absence listings in range charts. Inspired by the work of Thierstein et al. (1977), we developed methods to acquire census data (Backman and Shackleton 1983, Rio et al. 1990a, Raffi, 1999). By combining census data with short sample distances, we aimed to improve both the stratigraphic precision and resolution by which calcareous nannofossil biohorizons were determined. Census data have the advantage that they permit independent as- sessments of the abundance behaviour and distribution of taxa, and hence the quality of the biohorizons. We have subsequently generated much data showing abundance variations of biostratigraphically important calcareous nannofossil taxa from marine sediments of Cenozoic age representing different low and middle latitude paleoenvironmental settings.

We here synthesise Miocene through Pleistocene data in order to a establish a basic biostratigraphic framework for relative dating of marine sediments using calcareous nannofossils. This synthesis clearly relies on the pioneering contributions by Erlend Martini and David Bukry, as many of the biohorizons they used for zonal boundary definitions have proven to provide consistent results. Several of their zonal boundary defining biohorizons, however, have proven less practical and explains the need for a revised biozonation. Our approach has been to employ a limited set of selected biohorizons in order to establish a relatively coarse and stable framework taking into account the biostratigraphic data that we have produced over nearly three decades, consistently using semi-quantitative methods and short sample distances. In addition, we here present some previously unpublished biostratigraphic data.

A secondary purpose has been to provide age estimates for all biohorizons. Age estimates of individual biohorizons are presented with their calibration references. In the Miocene through Pleistocene interval, the independent age control is provided primarily by astronomically tuned cyclostratigraphies.

\section{Biozones, defining biohorizons and a revised biozone code system}

A biostratigraphic unit, or biozone, is a body of strata that are defined on the basis of its unique content, sequential distribution, absence, or combinations thereof, of fossils. Here, we use selected calcareous nannofossil biohorizons to establish a revised biozonation for the Miocene through Pleistocene interval.

The major advantage of using a logically organised zonal scheme, e.g., Zone CN5 is relatively older than Zone CN6, etc., is its ease of use compared to learning and remember the names of the many taxa providing individual biohorizons and biozone boundary definitions. In our view, biozones in a zonal scheme should represent a relatively coarse and stable framework us- 
ing carefully selected biohorizons for defining zonal boundaries rather than seeking to achieve the highest possible resolution. Other biostratigraphically useful biohorizons occur in virtually every biozone. We prefer to list these as biohorizons and their proper relative positions within the biozones as intra-zonal markers rather than to employ all or most of them for zonal boundary definitions, for the purpose to give stability to the zonal scheme and keep it simple. These latter points have motivated our reluctance to introduce subzones. Each biozone boundary should be defined by a single biohorizon. It follows that the use of 'auxiliary' biozone boundary markers is to be avoided.

Biozones may be defined using different concepts. We follow Wade et al. (2011) for five logical types of biozones that can be based on stratigraphic distributions of calcareous nannofossil taxa. These zones include:

1. Taxon Range Zone (TRZ)

2. Concurrent Range Zone (CRZ)

3. Base Zone (BZ)

4. Top Zone (TZ)

5. Partial Range Zone (PRZ)

However, Wade et al. (2011) used Lowest Occurrence (LO) and Highest Occurrence (HO) for categories 3 and 4, respectively. The commonly used acronym LO may refer to both Last Occurrence and Lowest Occurrence in calcareous nannoplankton biostratigraphy (e.g., Rio et al. 1984, Fornaciari et al. 2010). We thus prefer to use Base (B) and Top (T), respectively, to describe the stratigraphic lowest and highest occurrences of taxa (Fig. 1). This practice is not new (Roth et al. 1971, Raffi et al. 1993, Backman and Raffi 1997), and is considered unambiguous in comparison to $\mathrm{HO}$ and
LO. The Base and Top concepts are here used in a chronostratigraphic sense. Although avoiding the use of $\mathrm{LO}$ and $\mathrm{HO}$ terms for the types of biohorizons in our proposed new calcareous nannofossil zonation, we adhere to the five types of biozones that were introduced by Wade et al. (2011) and that can be applied to all biozones introduced below.

In our calcareous nannofossil biostratigraphy, we have used three concepts that differ from the absolutely topmost or basalmost stratigraphic presence of taxa. It is not uncommon that the first evolutionary appearance of a taxon is characterised by discontinuous occurrences of rare to few specimens for some stratigraphic distance below its continuous presence at higher abundances. Similarly, a tail of discontinuous occurrences of rare to few specimens may exist above its continuous presence at higher abundances. A typical example of this phenomenon is illustrated below by the Base of common Discoaster asymmetricus. In such cases, the absolutely lowest or highest occurrences are considered to provide a less reliable biostratigraphic signal when compared to the base and top of the continuous occurrences of the taxon at higher abundances. In such cases, we use the concepts Base common (Bc) and Top common (Tc). Several other possibilities to codify such biohorizons have been published, although we here refer to them as Tc or Bc. Another, more unusual, concept that we have adopted is the cross-over $(\mathbf{X})$ in abundance between two taxa. The two taxa may or may not be ancestor and descendant taxa. The key problem is that low and discontinuous abundances towards the end of the range of a (in some cases, ancestor) taxon and in the beginning of the range of another (in some cases, descendant) taxon may be difficult to determine precisely in terms of

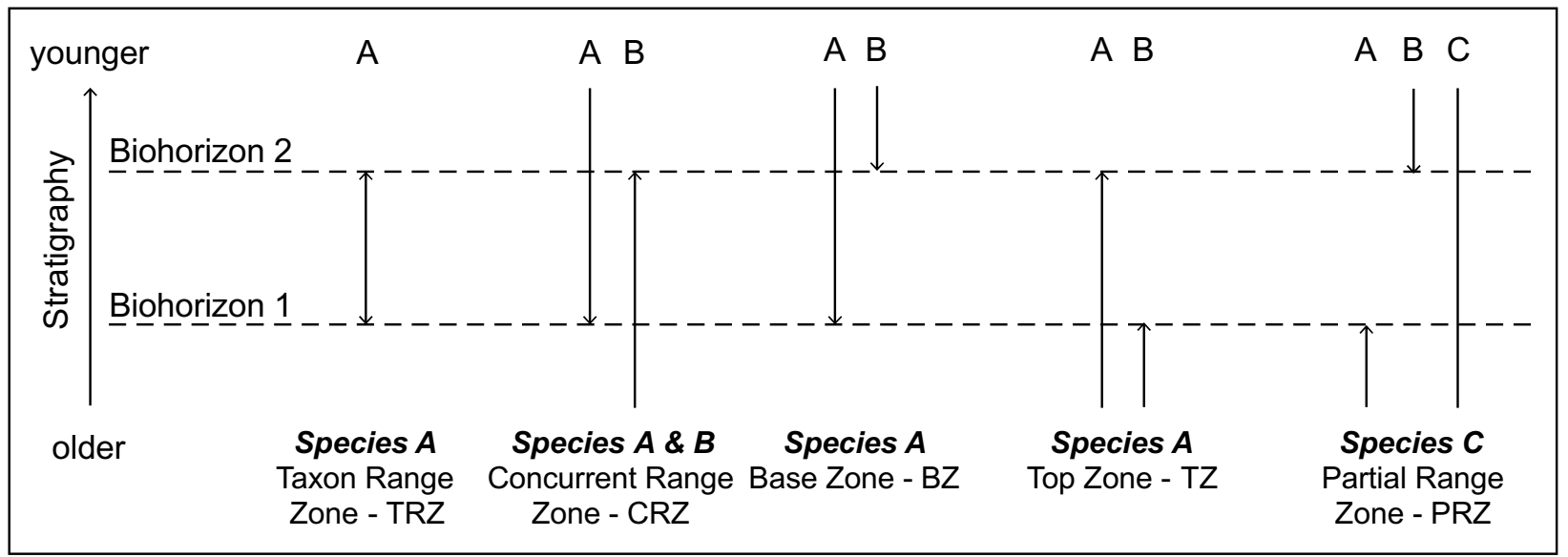

Fig. 1. The five logical possibilities for biostratigraphic characterization of biozones. Redrawn after Wade et al. (2011). 
stratigraphic depth. In cases where the cross-over occurs between ancestor and descendant taxa, the problem may be extended to include presence of intermediate and overlapping morphotypes, although the cross-over in abundance between the ancestor and descendant taxa may be readily determined. The crossover in abundance between Helicosphaera euphratis and Helicosphaera carteri is an example (see below) that do not appear to represent a direct ancestor/descendant (Haq 1973, Perch-Nielsen 1985), yet biostratigraphically useful, transition. The transition between Ceratolithus acutus and Ceratolithus rugosus, on the other hand, represents an illustrative example of an ancestor-descendant, biostratigraphically useful, transition (Backman and Raffi 1997).

Moreover, we use intervals in which an established species or genus temporarily disappears, to re-appear higher up in the stratigraphic column. Such absence intervals provide meaningful biostratigraphic information in a few cases. We thus refer to Base absence (Ba) for the temporary disappearance of Reticulofenstra pseudoumbilicus from the upper Miocene stratigraphic records and Top absence (Ta) for its re-entrance higher up in the upper Miocene stratigraphic column. Similarly, we use Ta for the biohorizon provided by the re-appearance of specimens $\geq 4 \mu \mathrm{m}$ among the Pleistocene genus Gephyrocapsa. Specimens $\geq 4 \mu \mathrm{m}$ first appears in the lower Pleistocene, followed by a stratigraphic interval of absence before this size class re-enters the stratigraphic record about 203 kyrs later. Size changes among the genus Gephyrocapsa have since long been successfully employed for stratigraphic subdivision of Pleistocene sediments (Gartner 1977, Rio 1982), including the re-entrance of specimens $\geq 4 \mu \mathrm{m}$ following an absence interval of such large specimens (Raffi et al. 1993).

Thus, we employ seven concepts to characterise biohorizons (B, Bc, Ba, T, Tc, Ta, X), which are used to define five different types of biozones (CRZ, TZ, BZ, PRZ, TRZ, Fig. 1), as illustrated by Wade et al. (2011).

In Cenozoic planktonic foraminifera biostratigraphy, recent revisions have introduced a biozone code system that adds a code letter for each series and a number system that begins at the base (= biozone 1 ) of the series (Berggren and Pearson 2006, Wade et al. 2011). We follow this system here, introducing a new code system for the Miocene through Holocene calcareous nannofossil biozones. We prefer to merge the Pliocene and Pleistocene in our chosen biozone code system, which is hence grouped into two units: Plio-
Pleistocene (PL) and Miocene (M). The following codes are used $(\mathrm{CN}=$ Calcareous Nannofossil):

1. CNPL1 to CNPL11: Pliocene through Pleistocene/ Holocene biozones 1 through 11

2. CNM1 to CNM19: Miocene biozones 1 through 20

A new Paleogene biostratigraphic zonation will be presented shortly in a different contribution, following the above approach and hence using $\mathrm{CNO}$ for Oligocene biozones, CNE for Eocene biozones and CNP for Paleocene biozones. The GSSP definitions of the Miocene, Pliocene and Pleistocene series boundaries (www.stratigraphy.org) are based on cyclostratigraphy (base Pleistocene, base Pliocene) and magnetostratigraphy (base Miocene). It follows that the above two groups of calcareous nannofossil biozones do not exactly coincide with the series boundaries, but are close enough to justify the code system. Of the four existing Miocene through Holocene series, the Holocene is too young $(0.012 \mathrm{Ma})$ in order to be distinguished biostratigraphically, and the controversial Pliocene/Pleistocene boundary is not distinguished in order to avoid future potential problems in the case that the boundary definition will change. Here we have chosen to use the chronostratigraphic scheme of Lourens et al. (2004), which places the base of the Pleistocene at the top of the Gelasian Stage at an age of 1.81 Ma.

\section{Age estimates of biohorizons}

Age estimates in the Miocene through Pleistocene interval are chiefly derived from astronomically tuned cyclostratigraphies. These estimates are considered to represent an improvement from our previous synthesis (Raffi et al. 2006) and include new calibrations. For age estimates of biohorizons derived from correlation to Pleistocene Marine Isotope Stages (MIS), we used Lisiecki and Raymo's (2005) MIS boundary estimates. For age estimates derived from orbitally tuned lithologic cyclicities (magnetic susceptibility) in ODP Sites 925 and 926, we used Shackleton and Crowhurst's (1997; Leg 154 CD-ROM Materials, Chapter 03 text files) age/depth tables. For age estimates derived from

1 These age estimates from ODP Site 926 in the western tropical Atlantic Ocean differ slightly from those originally presented by Backman and Raffi (1997) from the identical site, who used an early (unpublished) version of Shackleton and Crowhurst's (1997) astronomically tuned magnetic susceptibility records. 
orbitally tuned lithologic cyclicities (gamma ray wet-bulk densities) in ODP Leg 138 sites, we converted the estimates from Shackleton et al. (1995) to the timescale of Lourens et al. (2004). For age estimates derived from lower Miocene cyclostratigraphies in ODP Hole 926B and ODP Site 1218, we used the orbitally tuned data produced by Pälike et al. (2006, 2007). In addition to astronomically tuned cyclostratigraphic age data, we have used magnetostratigraphy for a few late Miocene biohorizons (Schneider 1995).

In the literature, there is an abundance of previous age estimates for each biohorizon presented here, e.g. Berggren et al. $(1985,1995)$ and the numerous Initial Reports volumes (see Explanatory Notes) of the Ocean Drilling Program. Here we show only our own calibrations generated from low and middle latitude settings.

\section{Biozone definitions in the Miocene interval}

Biozones are presented in chronological order, from older to younger. The biohorizons that are used for de- finitions of the CNM biozones are summarized in Table 1. Age estimates of zonal boundary markers and additional biohorizons in the Miocene interval are summarized in Table 2. The average error of age estimates for the 41 Miocene biohorizons is \pm 0.02 million years, as deduced from Table 2 (depth uncertainty divided by sedimentation rate). An overview of the CNM zonation in a chronostratigraphic context, and comparison with Okada and Bukry's (1980) and Martini's (1971) Miocene zonations, is shown in Figure 2.

Name: Zone CNM1 - Sphenolithus conicus Partial Range Zone

Definition: Partial range of the nominate taxon between the Top of Sphenolithus delphix and the Base of Sphenolithus disbelemnos.

Reference section: ODP Site 1218 (central part of tropical Pacific Ocean)

Estimated age: $23.06 \mathrm{Ma}-22.41 \mathrm{Ma}$ (Fig. 2, Table 2) Duration: 0.65 million years

Remarks: Martini (1971) defined Zone NN1 by the disappearance of Helicosphaera recta and the appearance of Discoaster druggii. The following zone, NN2, encompasses the interval from the $D$.druggii biohori-

Table 1 Biohorizons used for definitions of Miocene biozones.

\begin{tabular}{|c|c|c|c|c|c|}
\hline Marker Taxon for Base of Zone & Type of Event & Marker Taxon for Top of Zone & Type of Event & Biozone* & Code \\
\hline Discoaster quinqueramus & Top & Ceratolithus acutus & Base & T. rugosus PRZ & $\mathrm{CNM} 20$ \\
\hline Nicklithus amplificus & Top & Discoaster quinqueramus & Top & D. quinqueramus $\mathrm{TZ}$ & CNM19 \\
\hline Nicklithus amplificus & Base & Nicklithus amplificus & Top & N. amplificus TRZ & CNM18 \\
\hline Amaurolithus primus & Base & Nicklithus amplificus & Base & A. primus $\mathrm{BZ}$ & CNM17 \\
\hline Discoaster berggrenii & Base & Amaurolithus primus & Base & D. berggrenii $\mathrm{BZ}$ & CNM16 \\
\hline Reticulofenestra pseudoumbilicus & Base absence & Discoaster berggrenii & Base & D. bellus BZ & CNM15 \\
\hline Discoaster hamatus & Top & Reticulofenestra pseudoumbilicus & Base absence & R. pseudoumbilicus PRZ & CNM14 \\
\hline Discoaster hamatus & Base & Discoaster hamatus & Top & D. hamatus TRZ & $\mathrm{CNM} 13$ \\
\hline Ceratolithus coalitus & Base & Discoaster hamatus & Base & C. coalitus $\mathrm{BZ}$ & $\mathrm{CNM} 12$ \\
\hline Discoaster kugleri & Top common & Ceratolithus coalitus & Base & C. exilis $\mathrm{PRZ}$ & CNM11 \\
\hline Discoaster kugleri & Base common & Discoaster kugleri & Top common & D. kugleri TRZ & CNM10 \\
\hline Calcidiscus premacintyrei & Base & Discoaster kugleri & Base common & D. variabilis $\mathrm{PRZ}$ & CNM9 \\
\hline Sphenolithus heteromorphus & Top & Calcidiscus premacintyrei & Base & C. premacintyrei $\mathrm{TZ}$ & CNM8 \\
\hline Discoaster signus & Base & Sphenolithus heteromorphus & Top & D. signus / S. heteromorphus CRZ & CNM7 \\
\hline Sphenolithus heteromorphus & Base common & Discoaster signus & Base & S. heteromorphus BZ & CNM6 \\
\hline Sphenolithus belemnos & Base & Sphenolithus heteromorphus & Base common & S. belemnos $\mathrm{BZ}$ & CNM5 \\
\hline Helicosphaera euphratis / H. carteri & Cross-Over & Sphenolithus belemnos & Base & H. carteri $P R Z$ & CNM4 \\
\hline Triquetrorhabdulus carinatus & Top common & Helicosphaera euphratis / H. carteri & Cross-Over & H. euphratis PRZ & CNM3 \\
\hline Sphenolithus disbelemnos & Base & Triquetrorhabdulus carinatus & Top common & S. disbelemnos / T. carinatus CRZ & $\mathrm{CNM} 2$ \\
\hline Sphenolithus delphix & Top & Sphenolithus disbelemnos & Base & S. conicus $\mathrm{PRZ}$ & CNM1 \\
\hline
\end{tabular}




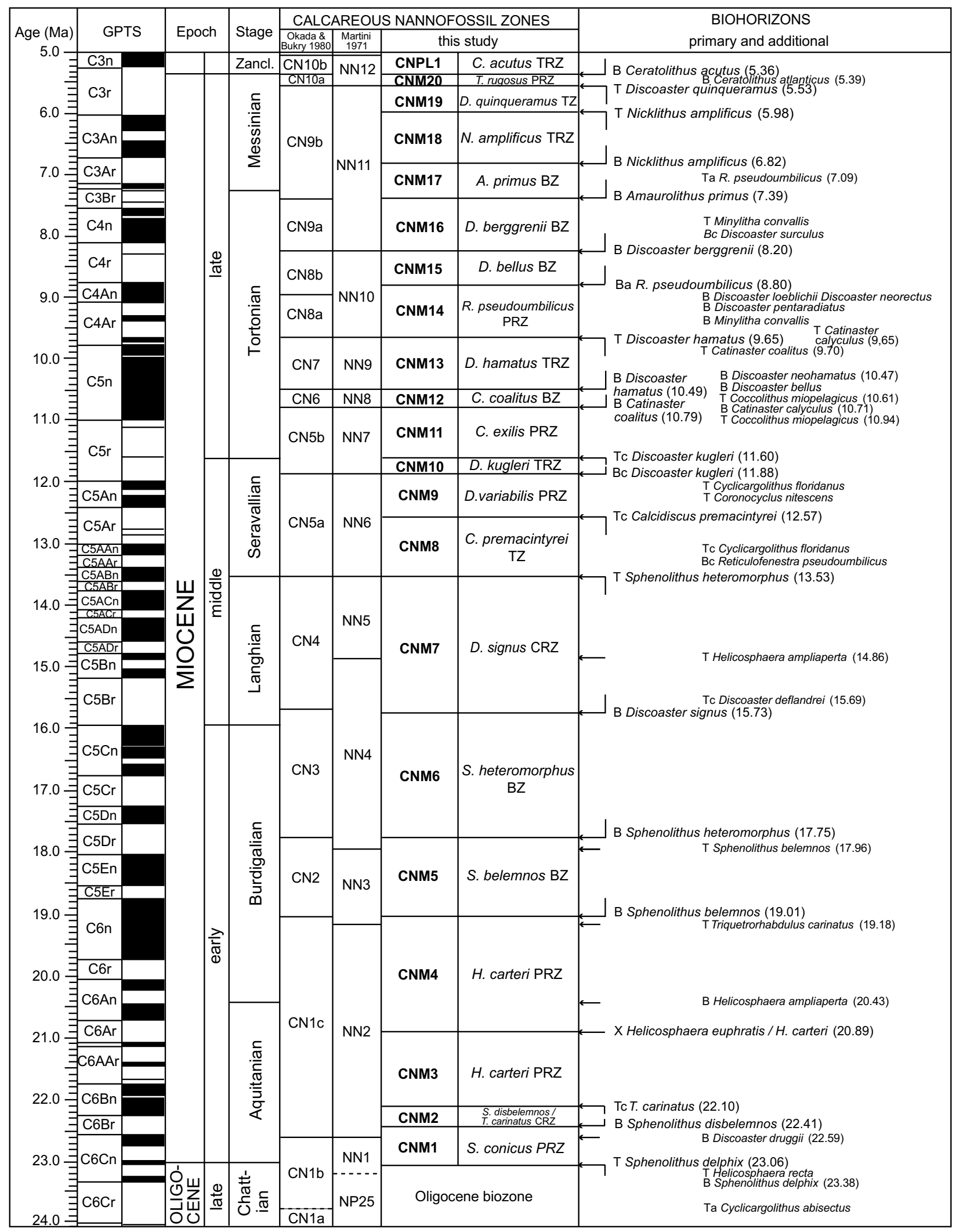

Fig. 2. Miocene through Pleistocene biozones and biohorizons are plotted versus the biozonations of Martini (1971) and Okada and Bukry (1980), and the Geomagnetic Polarity Time Scale (GPTS; Lourens et al. 2004). Abbreviations are explained in the text and in Table 1. Zancl. = Zanclean. 
Table 2 Age estimates of biohorizons. Biohorizons defining biozone boundaries are marked in bold. mcd - meters composite depth. Acronyms used for depth and age columns are: SC97 - Shackleton and Crowhurst 1997; DAS95 Schneider 1995; LL04 - Lourens et al. 2004; PÄL06 - Pälike et al. 2006; PÄL07 - Pälike et al. 2007.

\begin{tabular}{|c|c|c|c|c|c|c|c|c|c|c|c|c|}
\hline \multirow[b]{2}{*}{ Event } & \multirow[b]{2}{*}{ Species } & \multirow[b]{2}{*}{ Reference } & \multirow{2}{*}{$\begin{array}{c}\text { Depth } \\
\text { med } \\
\end{array}$} & \multirow[b]{2}{*}{$\pm \mathrm{m}$} & \multirow{2}{*}{$\begin{array}{l}\text { ODP } \\
\text { Hole }\end{array}$} & \multicolumn{2}{|c|}{ Interpolation between } & \multicolumn{2}{|c|}{ Interpolation between } & \multirow{2}{*}{\begin{tabular}{|c|} 
Rate \\
$\mathrm{m} / \mathrm{myr}$ \\
\end{tabular}} & \multirow{2}{*}{$\begin{array}{c}\text { Age } \\
\text { Ma }\end{array}$} & \\
\hline & & & & & & Upper Depth & Lower Depth & Younger Age & Older Age & & & \\
\hline \multirow{7}{*}{\begin{tabular}{l|l} 
B & B \\
В \\
T \\
T \\
B
\end{tabular}} & \multirow{7}{*}{$\begin{array}{l}\text { C. larrymayeri } \\
\text { C. acutus } \\
\text { C. atlanticus } \\
\text { D. quinqueramus } \\
\text { N. amplificus } \\
\text { N. amplificus } \\
\end{array}$} & \multirow{7}{*}{$\begin{array}{l}\text { Backman \& Raffi, } 1997 \\
\text { Backman \& Raffi, } 1997 \\
\text { Backman \& Raffi, } 1997 \\
\text { Backman \& Raffi, } 1997 \\
\text { Backman \& Raffi, } 1997 \\
\text { Backman \& Raffi, } 1997 \\
\end{array}$} & \multirow{2}{*}{161.46} & \multirow[b]{2}{*}{0.05} & & SC97 & SC97 & SC97 & SC97 & & & \\
\hline & & & & & $926 \mathrm{~A}$ & 161.21 & 161.41 & 5.32 & 5.34 & 10.0 & 5.35 & \\
\hline & & & 162.16 & 0.05 & $926 \mathrm{~A}$ & 161.71 & 162.71 & 5.34 & 5.39 & 20.0 & 5.36 & \\
\hline & & & 162.66 & 0.05 & $926 \mathrm{~A}$ & 161.71 & 162.71 & 5.34 & 5.39 & 20.0 & 5.39 & \\
\hline & & & 165.49 & 0.10 & $926 \mathrm{C}$ & 165.46 & 165.91 & 5.53 & 5.55 & 22.5 & 5.53 & \\
\hline & & & 175.66 & 0.05 & $926 \mathrm{C}$ & 175.56 & 176.06 & 5.98 & 6.00 & 25.0 & 5.98 & \\
\hline & & & 190.94 & 0.05 & $926 \mathrm{~B}$ & 190.71 & 191.01 & 6.80 & 6.82 & 15.0 & 6.82 & \\
\hline & & & & & & DAS95 & DAS95 & LL04 & LL04 & & & \\
\hline & & & & & & C3An.2n (o) ${ }^{1}$ & $\mathrm{C} 3 \mathrm{Bn}(\mathrm{y})$ & C3An.2n (o) & $\mathrm{C} 3 \mathrm{Bn}(\mathrm{y})$ & & & Mean age \\
\hline B & N. amplificus & Raffi \& Flores, 1995 & 39.19 & 0.15 & $844 \mathrm{~B}$ & 38.65 & 41.00 & 6.73 & 7.140 & 5.8 & 6.83 & $844 / 845$ \\
\hline $\mathrm{B}$ & N. amplificus & Raffi \& Flores, 1995 & 96.50 & 0.22 & $845 \mathrm{~A}$ & 96.28 & 101.18 & 6.73 & 7.140 & 12.0 & 6.75 & 6.79 \\
\hline & & & & & & sc97 & sc97 & sc97 & $\operatorname{seg} 7$ & & & \\
\hline $\mathrm{Ta}$ & R. pseudoumbilicus & Backman \& Raffi, 1997 & 195.14 & 0.05 & $926 \mathrm{~B}$ & 195.11 & 195.76 & 7.09 & 7.14 & 13.0 & 7.09 & \\
\hline & & & & & & DAS95 & DAS95 & LL04 & LL04 & & & \\
\hline & & & & & & C3An.2n (o) & $\mathrm{C} 3 \mathrm{Bn}(\mathrm{y})$ & C3An.2n (o) & $\mathrm{C} 3 \mathrm{Bn}(\mathrm{y})$ & & & Mean age \\
\hline $\mathrm{Ta}$ & R. pseudoumbilicus & Raffi \& Flores, 1995 & 40.99 & 0.15 & $844 B$ & 38.65 & 41.00 & 6.73 & 7.140 & 5.8 & 7.14 & $844 / 845$ \\
\hline $\mathrm{Ta}$ & R. pseudoumbilicus & Raffi \& Flores, 1995 & 99.26 & 0.28 & $845 \mathrm{~A}$ & 96.28 & 101.18 & 6.73 & 7.140 & 12.0 & 6.98 & 7.06 \\
\hline & & & & & & SC97 & SC97 & SC97 & SC97 & & & \\
\hline B & A. primus & Backman \& Raffi, 1997 & 199.79 & 0.05 & $926 \mathrm{~A}$ & 198.91 & 200.01 & 7.35 & 7.40 & 22.0 & 7.39 & \\
\hline & & & & & & DAS95 & DAS95 & LL04 & LL04 & & & \\
\hline & & & & & & C3Bn (y) & C4n.1n (y) & C3Bn (y) & $\mathrm{C} 4 \mathrm{n} . \ln (\mathrm{y})$ & & & Mean age \\
\hline B & A. primus & Raffi \& Flores, 1995 & 42.65 & 0.30 & $844 \mathrm{~B}$ & 41.80 & 43.15 & 7.140 & 7.528 & 3.5 & 7.38 & $844 / 845$ \\
\hline $\mathrm{B}$ & A. primus & Raffi \& Flores, 1995 & 106.18 & 1.50 & $845 \mathrm{~A}$ & 101.18 & 108.06 & 7.140 & 7.528 & 17.7 & 7.42 & 7.40 \\
\hline & & & & & & $\mathrm{SC} 97$ & $\mathrm{SC} 97$ & $\mathrm{SC} 97$ & $\mathrm{SC} 97$ & & & \\
\hline B & D. berggrenii & Backman \& Raffi, 1997 & 217.60 & 0.56 & $926 \mathrm{~B} / \mathrm{C}$ & 198.91 & 200.01 & 7.35 & 7.40 & 22.0 & 8.20 & \\
\hline & & & & & & DAS95 & DAS95 & LL04 & LL04 & & & \\
\hline & & & & & & C $4 n .2 n(o)$ & C4An (y) & C $4 n .2 n(o)$ & C4An (y) & & & Mean age \\
\hline B & D. berggrenii & Raffi \& Flores, 1995 & 53.30 & 1.15 & $844 \mathrm{C}$ & 49.95 & 56.75 & 8.108 & 8.769 & 10.3 & 8.43 & $844 / 845$ \\
\hline & D. berggrenii & Raffi \& Flores, 1995 & 126.41 & 0.25 & $845 \mathrm{~A}$ & 119.28 & 129.71 & 8.108 & 8.769 & 15.8 & 8.56 & 8.50 \\
\hline & & & & & & scy7 & Scy7 & Scy7 & SC97 & & & \\
\hline $\mathrm{Ba}$ & R. pseudoumbilicus & Backman \& Raffi, 1997 & 225.51 & 0.20 & $926 \mathrm{~B}$ & 225.31 & 225.71 & 8.79 & 8.81 & 20.0 & 8.80 & \\
\hline $\mathrm{T}$ & D. hamatus & Backman \& Raffi, 1997 & 237.77 & 0.35 & $926 \mathrm{~B}$ & 237.51 & 238.16 & 9.63 & 9.67 & 16.3 & 9.65 & \\
\hline $\mathrm{T}$ & C. calyculus & Backman \& Raffi, 1997 & 237.87 & 0.05 & $926 \mathrm{~B}$ & 237.51 & 238.16 & 9.63 & 9.67 & 16.3 & 9.65 & \\
\hline $\mathrm{T}$ & C. coalitus & Backman \& Raffi, 1997 & 238.67 & 0.05 & $926 \mathrm{~B}$ & 238.16 & 239.41 & 9.67 & 9.74 & 17.9 & 9.70 & \\
\hline B & D. neohamatus & Backman \& Raffi, 1997 & 249.22 & 0.05 & $926 \mathrm{~B}$ & 248.61 & 249.31 & 10.43 & 10.48 & 14.0 & 10.47 & \\
\hline B & D. hamatus & Backman \& Raffi, 1997 & 249.62 & 0.15 & $926 \mathrm{~B}$ & 249.31 & 250.31 & 10.48 & 10.52 & 25.0 & 10.49 & \\
\hline & & & & & & DAS95 & DAS95 & LL04 & LL04 & & & \\
\hline $\mathrm{T}$ & C. miopelagicus (Pacific) & Raffi \& Flores, 1995 & 159.20 & 0.15 & $845 \mathrm{~B}$ & $\begin{array}{c}\text { C } 4 n .2 n(o) \\
150.80 \\
\end{array}$ & $\begin{array}{c}\text { C4An (y) } \\
166.05 \\
\end{array}$ & $\begin{array}{c}\mathrm{C} 4 \mathrm{n} .2 \mathrm{n}(\mathrm{o}) \\
9.987 \\
\end{array}$ & $\begin{array}{c}\text { C4An (y) } \\
11.118 \\
\end{array}$ & 13.5 & 10.61 & \\
\hline & & & & & & SC97 & SC97 & SC97 & SC97 & & & \\
\hline B & C. calyculus & Backman \& Raffi, 1997 & 252.65 & 0.15 & $926 \mathrm{~A}$ & 252.26 & 252.96 & 10.68 & 10.73 & 14.0 & 10.71 & \\
\hline B & C. coalitus & Backman \& Raffi, 1997 & 253.65 & 0.05 & $926 \mathrm{~A}$ & 253.36 & 254.26 & 10.77 & 10.84 & 12.9 & 10.79 & \\
\hline $\mathrm{T}$ & C. miopelagicus (Atlantic) & Backman \& Raffi, 1997 & 255.45 & 0.15 & $926 \mathrm{~A}$ & 255.41 & 255.91 & 10.94 & 10.98 & 12.5 & 10.94 & \\
\hline $\mathbf{T e}$ & D. kugleri & Backman \& Raffi, 1997 & 262.96 & 0.05 & $926 \mathrm{~A}$ & 262.96 & 262.96 & 11.60 & 11.60 & $\mathrm{n} / \mathrm{a}$ & 11.60 & \\
\hline $\mathrm{Bc}$ & D. kugleri & Backman \& Raffi, 1997 & 266.16 & 0.05 & $926 \mathrm{~A}$ & 266.11 & 266.51 & 11.88 & 11.90 & 20.0 & 11.88 & \\
\hline Te & C. premacintyrei & This study & 276.77 & 0.05 & $926 \mathrm{~B}$ & 275.46 & 277.66 & 12.46 & 12.64 & 12.2 & 12.57 & \\
\hline $\mathrm{T}$ & S. heteromorphus & Backman \& Raffi, 1997 & 294.06 & 0.20 & $926 \mathrm{~B}$ & 294.00 & 294.40 & 13.53 & 13.55 & 20.0 & 13.53 & \\
\hline & & & & & & Heil & Pălike, person & mmunication & & & & \\
\hline $\mathrm{T}$ & H. ampliaperta & Curry, Shackleton et al., 1995 & 366.72 & 0.38 & $925 \mathrm{D}$ & 366.43 & 367.14 & 14.85 & 14.87 & 28.4 & 14.86 & \\
\hline $\mathrm{Tc}$ & D. deflandrei & This study & 395.89 & 0.05 & $925 \mathrm{D}$ & 395,24 & 396.09 & 15.66 & 15.70 & 21.8 & 15.69 & \\
\hline B & D. signus & This study & 396.92 & 0.08 & $925 \mathrm{D}$ & 396.09 & 397.14 & 15.70 & 15.74 & 25.6 & 15.73 & \\
\hline B & S. heteromorphus & This study & 346.91 & 0.10 & $926 \mathrm{~B}$ & 346.83 & 346.93 & 17.73 & 17.74 & 6.3 & 17.74 & \\
\hline & & & & & & PÄL07 & PÄL07 & PÄL07 & PÄL07 & & & \\
\hline $\mathrm{T}$ & S. belemnos & This study & 352.01 & 0.50 & $926 \mathrm{~B}$ & 351.93 & 352.13 & 17.934 & 17.941 & 28.6 & 17.94 & \\
\hline B & S. belemnos & Curry, Shackleton et al., 1995 & 382.88 & 0.55 & $926 \mathrm{~B}$ & 382.83 & 382.93 & 19.006 & 19.010 & 25.0 & 19.01 & \\
\hline
\end{tabular}

1 (y) - younger side of geomagnetic polarity chron; (o) - older side of geomagnetic polarity chron. 
Table 2 Age estimates of biohorizons. Biohorizons defining biozone boundaries are marked in bold. mcd - meters composite depth. Acronyms used for depth and age columns are: SC97 - Shackleton and Crowhurst 1997; DAS95 Schneider 1995; LL04 - Lourens et al. 2004; PÄL06 - Pälike et al. 2006; PÄL07 - Pälike et al. 2007.

\begin{tabular}{|c|c|c|c|c|c|c|c|c|c|c|c|}
\hline \multirow[b]{2}{*}{$\mathrm{T}$} & \multirow[b]{2}{*}{ T. carinatus } & \multirow[b]{2}{*}{ Pälike et al., 2005} & \multirow{2}{*}{$\begin{array}{r}\text { rmcd }^{3} \\
63.63 \\
\end{array}$} & \multirow[b]{2}{*}{1.28} & \multirow[b]{2}{*}{$1218 \AA$} & PÄL06 ${ }^{4}$ & PÄL06 & PÄL06 & PÄL06 & \multirow[b]{2}{*}{7.5} & \multirow[b]{2}{*}{19.18} \\
\hline & & & & & & 62.35 & 64.91 & 19.013 & 19.353 & & \\
\hline \multirow{3}{*}{$\begin{array}{l}\mathrm{B} \\
\mathbf{X} \\
\end{array}$} & \multirow{3}{*}{$\begin{array}{l}\text { H. ampliaperta } \\
\text { H. euphratis/H. carteri }\end{array}$} & \multirow{3}{*}{$\begin{array}{l}\text { Curry, Shackleton et al., } 1995 \\
\text { Fornaciari, } 1996^{2}\end{array}$} & \multirow{3}{*}{$\begin{array}{l}421.46 \\
435.51 \\
\end{array}$} & \multirow{3}{*}{$\begin{array}{l}0.35 \\
0.40 \\
\end{array}$} & \multirow{3}{*}{$\begin{array}{l}926 \mathrm{~B} \\
926 \mathrm{~B} \\
\end{array}$} & PÄL07 & PÄL07 & PÄL07 & PÄL07 & \multirow{3}{*}{$\begin{array}{l}25.0 \\
28.6 \\
\end{array}$} & \multirow{3}{*}{$\begin{array}{l}20.43 \\
\mathbf{2 0 . 8 9} \\
\end{array}$} \\
\hline & & & & & & 421.41 & 421.51 & 20.423 & 20.427 & & \\
\hline & & & & & & 435.41 & 435.61 & 20.890 & 20.897 & & \\
\hline \multirow{2}{*}{ Te } & \multirow[b]{2}{*}{ T. carinatus } & \multirow[b]{2}{*}{ This study } & \multirow{2}{*}{$\begin{array}{l}\text { rmed } \\
87.21\end{array}$} & \multirow[b]{2}{*}{0.05} & \multirow[b]{2}{*}{$1218 \mathrm{~A}$} & PÄL06 & PÄL06 & PÄL06 & PÄL06 & \multirow[b]{2}{*}{10.0} & \multirow[b]{2}{*}{22.10} \\
\hline & & & & & & 87.18 & 87.23 & 22.101 & 22.106 & & \\
\hline $\mathbf{B}$ & S. disbelemnos & This study & 90.51 & 0.25 & $1218 \mathrm{~A}$ & 90.51 & 90.51 & 22.413 & 22.413 & $\mathrm{n} / \mathrm{a}$ & 22.41 \\
\hline $\mathrm{B}$ & D. druggii (Pacific) ${ }^{5}$ & Pälike et al., 2006 & 96.46 & 0.20 & $1218 \mathrm{~A}$ & 92.46 & 92.46 & 22.592 & 22.592 & $\mathrm{n} / \mathrm{a}$ & 22.59 \\
\hline $\mathbf{T}$ & S. delphix & This study & 96.65 & 0.05 & $1218 \mathrm{~B}$ & 96.65 & 96.65 & 23.062 & 23.062 & $\mathrm{n} / \mathrm{a}$ & 23.06 \\
\hline $\mathrm{B}$ & S. delphix & This study & 100.65 & 0.05 & $1218 \mathrm{~A}$ & 100.27 & 100.77 & 23.345 & 23.390 & 11.1 & 23.38 \\
\hline
\end{tabular}

2 Unpublished PhD thesis; plot shown in this study.

3 Pälike et al. (2005); rmcd - revised meters composite depth.

4 http://doi.pangaea.de/10.1594/PANGAEA.547797; Pälike et al. (2006, reference 7).

5 This biohorizon occurs $<3 \mathrm{~m}$ above Top S.delphix in the Indian Ocean, ODP Hole 709C (Fornaciari 1996; see 2 above).

zon to the disappearance of T.carinatus. Okada and Bukry (1980) employed the interval between the disappearances of Sphenolithus ciperoensis and Dictyococcites bisectus and the end of the "acme" of Cyclicargolithus abisectus to define Subzone CN1a, the interval between the C.abisectus biohorizon and the appearance of $D$. druggii to define Subzone CN1b, and the interval between the D.druggii biohorizon and the appearance of Sphenolithus belemnos to define Subzone CN1c. However, the biohorizons provided by H.recta, D.druggii, T.carinatus, D. bisectus and C.abisectus all show problematic distributions, as expressed, for example, by Rio et al. (1990b, p. 182183): "Helicosphaera recta rarely occur in oceanic sediments [...] because H.recta and D.bisectus are rare, the established relationships may be of only local value". They also remark that "no acme was recognized [...] of C.abisectus. Medium-sized C.abisectus are distributed as high as up as the lower part of Zone $\mathrm{NN} 4$, with no increase in abundance evident in the interval between the $\mathrm{LO}$ of S.ciperoensis and the FO of D. druggii." Rio et al. furthermore discuss the problems of the sporadic occurrences of D.druggii, and noticed the "short acme interval of Sphenolithus delphix, slightly below the FO of D.druggii, at all the sites investigated". At Site 709 in the tropical Indian Ocean, D. druggii appears $<3 \mathrm{~m}$ above the disappearance of S.delphix within a single core (Core 709C21X) (Fornaciari 1996). This suggests that D.druggii has a time transgressive appearance, probably occurring a few hundred thousand years earlier in the tropi- cal Indian Ocean compared to its first rare occurrences in the central tropical Pacific Ocean (Table 4). In conclusion, the set of biohorizons employed by Martini (1971) and Okada and Bukry (1980) for biostratigraphic subdivision of the uppermost Oligocene through lowermost Miocene stratigraphy is presently considered to be of limited quality.

An abundance plot of the two taxa used for defining Zone CNM1 is shown in Figure 3. The OligoceneMiocene boundary at 23.030 Ma (Lourens et al. 2004) falls $30 \mathrm{ka}$ after the onset of Zone CNM1 (Fig.2), shortly after the disappearance of S.delphix.

Name: Zone CNM2 - Triquetrorhabdulus carinatus/ Sphenolithus disbelemnos Concurrent Range Zone

Definition: Concurrent range of the nominate taxa between the Base of S.disbelemnos and the Top of common T.carinatus.

Reference section: ODP Site 1218 (central part of tropical Pacific Ocean)

Estimated age: $22.41 \mathrm{Ma}-22.10 \mathrm{Ma}$ (Fig. 2, Table 2)

Duration: 0.31 million years

Remarks: This zone corresponds to the lower parts of both Zone NN2 of Martini (1971) and Subzone CN1c of Okada and Bukry (1980), respectively.

Remarks on assemblages: In this short biostratigraphic interval, the nominate taxon S.disbelemnos is not particularly abundant but is consistently recorded in the low latitude Indian, Pacific and Atlantic oceans (Rio et al. 1990 - referred to as S.dissimilis - S.belemnos intergrade; Fornaciari et al. 1993 - referred to as 
S.dissimilis/S.belemnos; Pälike et al. 2006, Shackleton et al. 2000), and in the Mediterranean region, including the Oligocene/Miocene GSSP Section of Lemme Carrosio (Fornaciari and Rio 1996, Raffi 1999). An abrupt decrease in abundance of T.carinatus has been observed well prior to its exinction in lower latitudes, which provides a more distinct biohorizon than its final disappearance. At ODP Site 1218 (Fig.4), the decrease occurs over a $10 \mathrm{~cm}$ interval, from an average of 24 specimens per $\mathrm{mm}^{2}$ in 79 samples above the decrease to an average of 415 specimens per $\mathrm{mm}^{2}$ in 149 samples below the decrease. Here, the change thus represents a factor of six decrease in abundance. The Top of common T.carinatus is near identical in terms of age in tropical Pacific Site 1218 (22.10 Ma, Table 2) and tropical Atlantic Site 929 (22.03 Ma, Flower et al. 1997, Shackleton et al. 2000; age estimates converted to the La_2004 astronomical solution by Heiko Pälike).

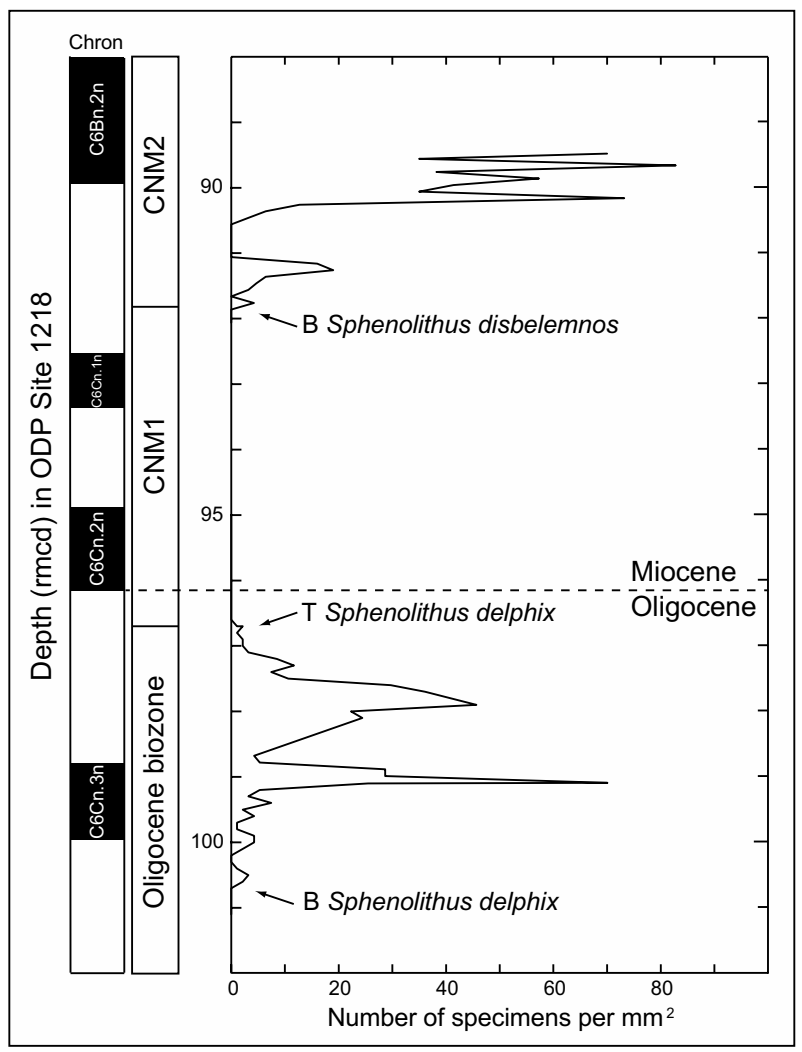

Fig. 3. Abundances of taxa defining biozones across the Oligocene-Miocene boundary at ODP Site 1218 in the tropical Pacific Ocean. Positions of geomagnetic polarity chrons and revised meters composite depths (rmcd) are from Pälike et al. (2005). Abundances of taxa are expressed as numbers per unit area on the smear-slides investigated.

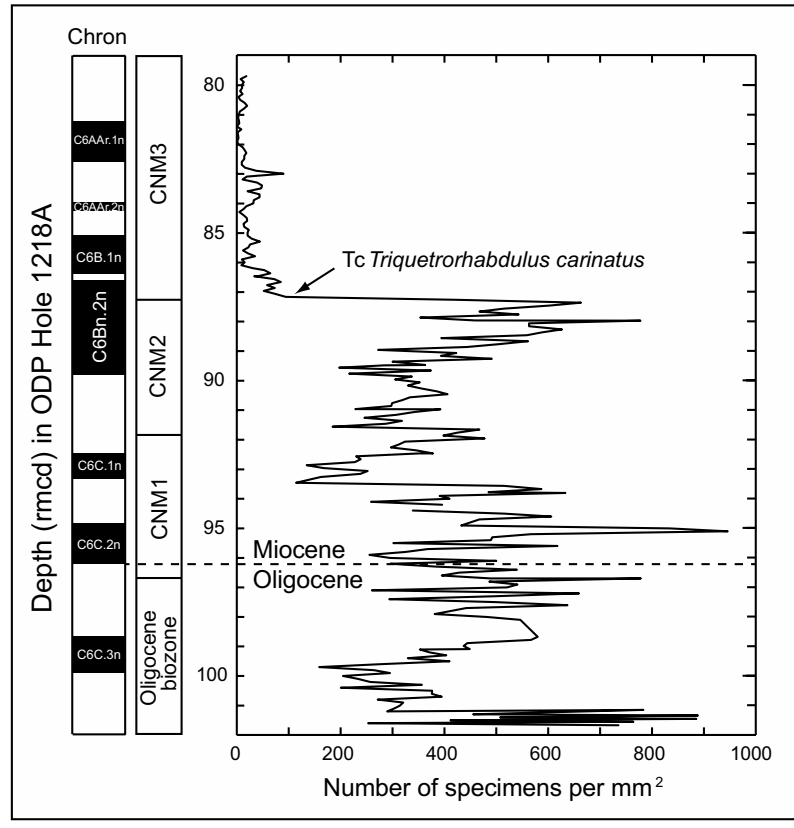

Fig. 4. The sharp 6-fold decrease in abundance of T.carinatus to values, here at ODP Site 1218 in the tropical Pacific Ocean, defines the Tc T. carinatus biohorizon. Positions of geomagnetic polarity chrons and revised meters composite depths (rmcd) are from Pälike et al. (2005). Abundances of taxa are expressed as numbers per unit area on the smearslides investigated. The Oligocene/Miocene boundary is defined at the base of Chron C6C.2n (Lourens et al. 2004).

Name: Zone CNM3 - Helicosphaera euphratis Partial Range Zone*

Definition: Biostratigraphic interval between the Top of common T.carinatus and the abundance cross-over between H.euphratis and H.carteri.

Reference section: ODP Site 1218 (lower biohorizon) and ODP Site 926 (upper biohorizon)

Estimated age: $22.10 \mathrm{Ma}-20.89 \mathrm{Ma}$ (Fig. 2, Table 2) Duration: 1.21 million years

Remarks: This zone corresponds to an interval in the lower part of Zone NN2 of Martini (1971) as well as of Subzone CN1c of Okada and Bukry (1980). *The use of a biohorizon provided by an abundance crossover is a modified version of the Partial Range Zone concept as presented by Wade et al. (2011). This abundance cross-over provides a useful biohorizon, however, to subdivide the relatively poorly resolved biostratigraphic interval of the lower Miocene.

Remarks on assemblages: Data showing the crossover between H.euphratis and H.carteri were originally presented by Fornaciari (1996), and here plotted in Figure 5. 


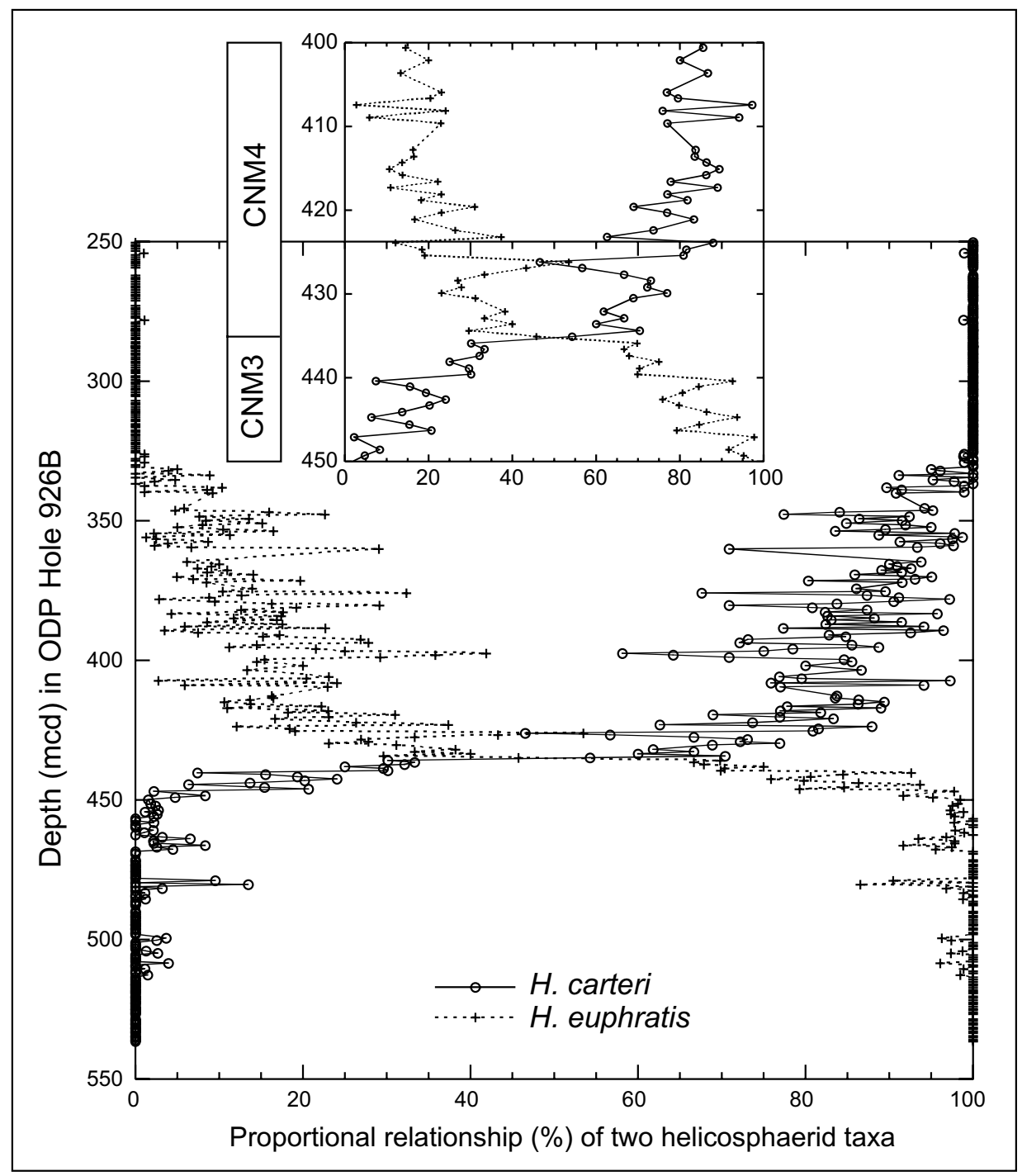

Fig. 5. Abundance cross-over between H.euphratis (dotted line) and H.carteri (solid line) from ODP Hole 926B in the western tropical Atlantic Ocean (Fornaciari 1996). Upper inserted panel shows an enlargement of the critical interval, which defines the CNM3/CNM4 biozone boundary.

Name: Zone CNM4 - Helicosphaera carteri Partial Range Zone*

Definition: Partial range of the nominate taxon between the abundance crossover between H.euphratis and H.carteri and the Base of Sphenolithus belemnos.

Reference section: ODP Site 926 (western tropical Atlantic Ocean)

Estimated age: 20.89 Ma-19.01 Ma (Fig. 2, Table 2)

Duration: 1.89 million years

Remarks: This zone corresponds to the upper parts of Zone NN2 of Martini (1971) and Subzone CN1c of Okada and Bukry (1980). *The use of a biohorizon provided by an abundance cross-over is a modified version of the Partial Range Zone concept as presented by Wade et al. (2011).

Remarks on assemblages: Base of Helicosphaera ampliaperta occurs in the lower part of this biozone. An overlap in the ranges between T.carinatus and S.belemnos was demonstrated by Fornaciari et al. (1990) from the Indian Ocean, and by Raffi et al. (2006) from the Atlantic Ocean. Previously, PerchNielsen (1985, p.443) remarked that "The FO of S.belemnos [...] usually is found slightly below the LO of T.carinatus." Low abundances in combination with sporadic occurrences of T.carinatus toward the 
end of its range makes this marker less reliable (Raffi et al. 2006).

Name: Zone CNM5 - Sphenolithus belemnos Base Zone

Definition: Biostratigraphic interval between the Base of the nominate taxon S.belemnos and the Base of common Sphenolithus heteromorphus.

Reference section: ODP Site 926 (lower boundary) and ODP Site 925 (upper boundary)

Estimated age: $19.01 \mathrm{Ma}-17.75 \mathrm{Ma}$ (Fig. 2, Table 2)

Duration: 1.26 million years

Remarks: This zone corresponds to Zone CN2 of Okada and Bukry (1980), and encompasses most of Zone NN3 of Martini (1971).

Remarks on assemblages: This biostratigraphic interval corresponds to the common and continuous range of the nominate taxon S.belemnos that shows a sharp decrease in abundance at the top of the biozone, occurring about 0.2 million years prior to the appearance of S.heteromorphus (Fig. 6). The calibration obtained for the latter biohorizon at ODP Site 926 (this study) conforms (within 0.01 million years) with the calibration suggested by shipboard data at ODP Site 925 (Curry, Shackleton et al. 1995).
Name: Zone CNM6 - Sphenolithus heteromorphus Base Zone

Definition: Biostratigraphic interval between the Base of the common nominate taxon S.heteromorphus and the Base of Discoaster signus.

Reference section: ODP Site 925 (western tropical Atlantic Ocean)

Estimated age: 17.75 Ma-15.73 Ma (Fig.2, Table 2) Duration: 2.02 million years

Remarks: This zone approximately corresponds to the lower part of Zone NN4 of Martini (1971) and is nearly identical to Zone CN3 of Okada and Bukry (1980). The latter used the end of the acme of D.deflandre $i$ to define the top of Zone CN3, whereas the appearance of $D$. signus is used here as a zonal boundary marker. Rio et al. (1990) introduced "the drop in abundance below $30 \%$ of D.deflandrei and the concomitant appearance of the D.tuberi $-D$. signus group to distinguish the NN4 (CN3) and NN5 (CN4) Zones in sites where H.ampliaperta is missing." The Base of D. signus and the Top of common (Tc) D.deflandrei are separated only by 0.04 million years (Table 2 , Fig. 7).

Remarks on assemblages: The genus Calcidiscus appears within this biostratigraphic interval.

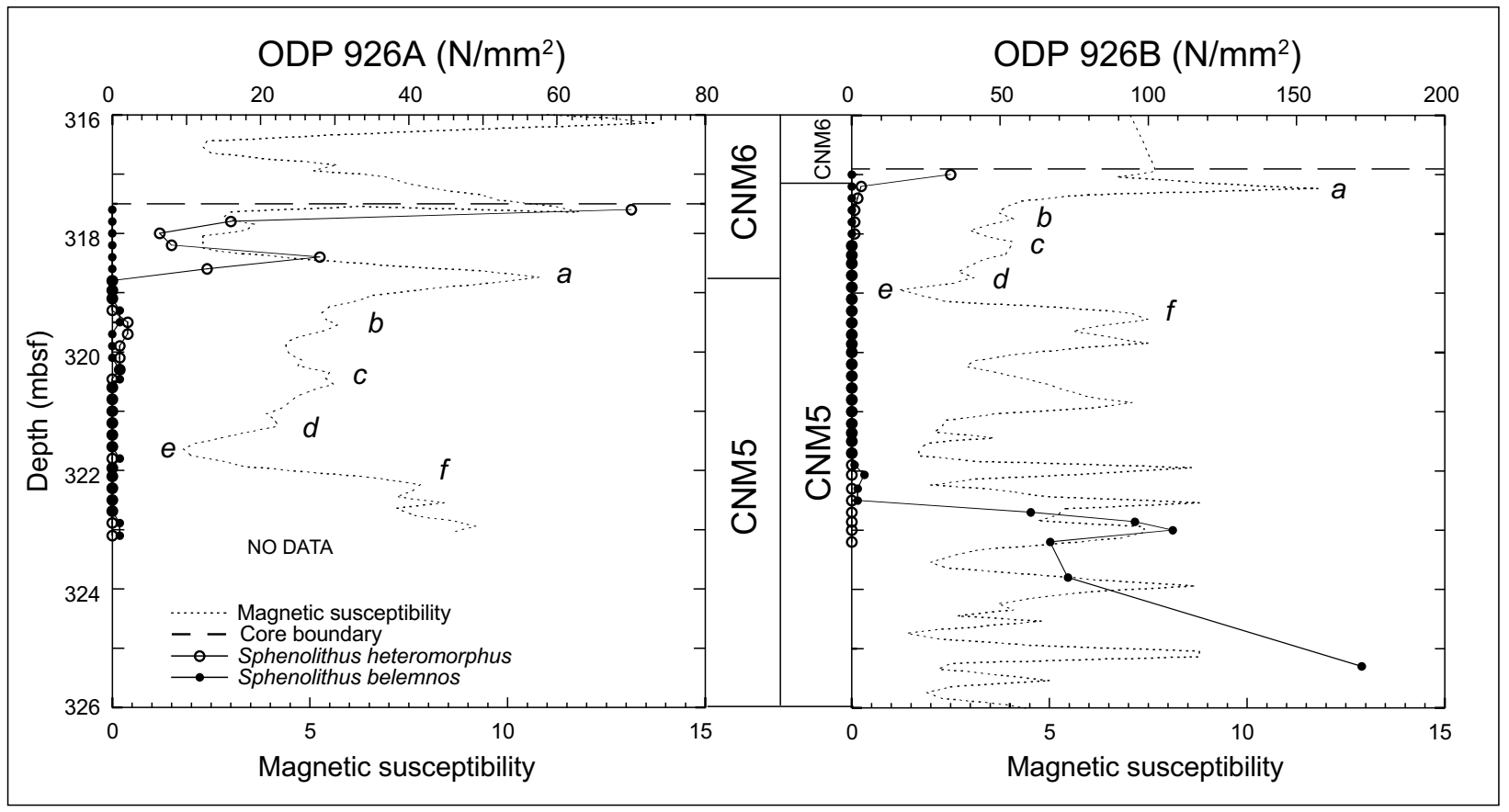

Fig. 6. Disappearance of S.belemnos and appearance of S. heteromorphus as recorded in ODP Site 926. The abundance distributions of the two taxa are expressed as number of specimens per unit area of the smear-slide $\left(\mathrm{N} / \mathrm{mm}^{2}\right)$. Peaks and troughs "a" to " $\mathrm{f}$ " in magnetic susceptibility shows a striking correlation between Holes 926A and 926B in a critical interval. 


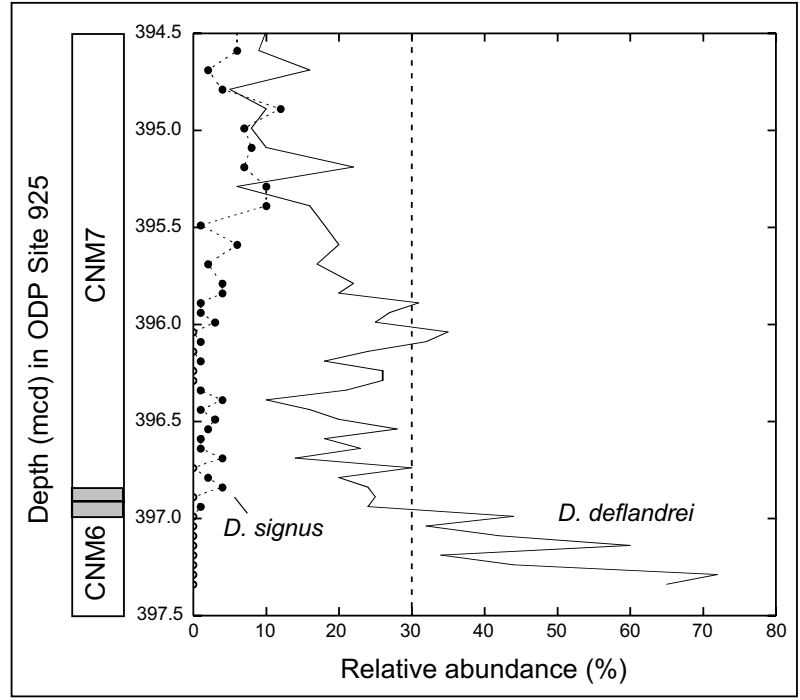

Fig. 7. Appearance of D. signus and sharp decrease in abundance of $D$.deflandrei in ODP Site 925 from the western tropical Atlantic Ocean. Both categories represent relative abundances versus the total number of all Discoaster spp.

Name: Zone CNM7 - Discoaster signus/Sphenolithus heteromorphus Concurrent Range Zone

Definition: Biostratigraphic interval between the Base of the nominate taxon D. signus and the Top of S.heteromorphus.

Reference section: ODP Site 925 (lower boundary) and ODP Site 926 (upper boundary)

Estimated age: 15.73 Ma-13.53 Ma (Fig. 2, Table 2)

Duration: 2.20 million years

Remarks: The upper part of this zone corresponds to Zone NN5 of Martini (1971). Zone CN4 of Okada and Bukry (1980) used two biohorizons to define the base of Zone CN4 (Sphenolithus heteromorphus Zone), namely Top common D.deflandrei and Top Helicosphaera ampliaperta, which are separated by about 0.8 million years (Table 2). Here, Top H. ampliaperta it is not used for a zonal boundary marker due to the discontinuous and scattered distribution in its upper range. The appearance of $D$. signus occurs close to the distinct decrease in abundance (Tc) of D. deflandrei in the tropical Indian, Pacific and Atlantic (Fig.7) oceans, and in the mid-latitude South Atlantic (Rio et al. 1990, Shackleton et al. 1995, Raffi et al. 2006, Zachos et al. 2004).

\section{Remarks on assemblages: Calcidiscus premacintyre $i$} appears and gradually increase in abundance within this biostratigraphic interval. In Mediterranean sections, the upper part of this biostratigraphic interval is characterised by the common presence of the small

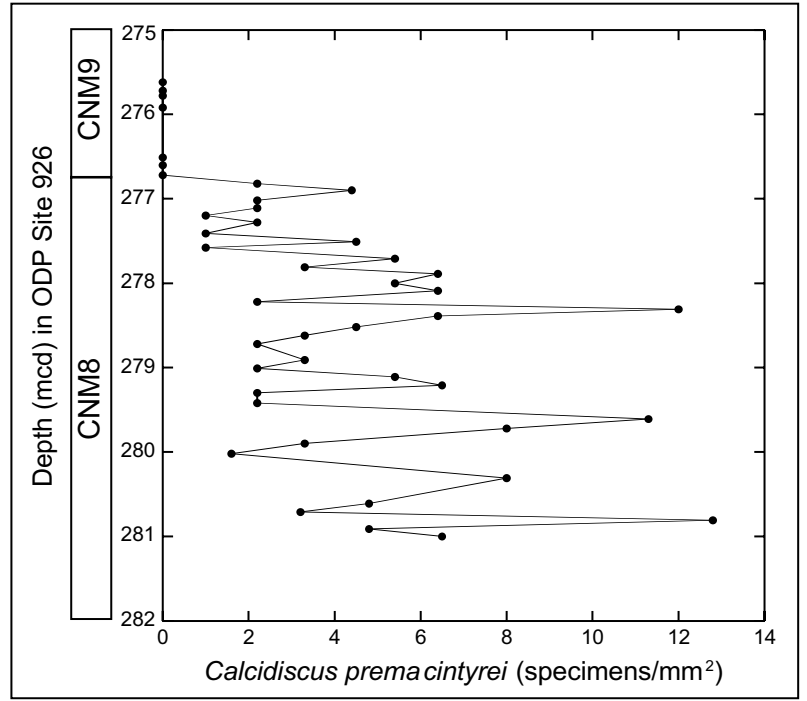

Fig. 8. Disapperance of C.premacintyrei as recorded in ODP Hole 926B.

Helicosphaera walbersdorfensis, that provides a useful biohorizon for regional biostratigraphy (Fornaciari et al. 1996).

There exists some confusion regarding the taxonomic status of $D$. signus. We consider that $D$. signus is a valid species and that Discoaster petaliformis Moshkovitz and Ehrlich (1980) and D.tuberi (Filewicz 1985) both are junior synonyms of D. signus Bukry (1971). In Nannotax (http://nannotax.org/content/discoaster-petaliformis, December 2011), however, it is argued that "This form was independently illustrated by Filewicz (1985) as D.tuberi; Theodoridis (1984) as D. signus, and Moshkovitz \& Ehrlich (1980) as D.petaliformis. The forms illustrated are of the same age (NN4-5) and extremely similar. They are clearly the same taxon, and given their distinctive form and restricted range it is useful to distinguish them. D.signus is an inappropriate name for them, since D. signus as described by Bukry (1971) lacks central knobs." The last statement is inconsistent with Bukry's (1971, p. 48) description: "a prominent knob forms the hub for the six equally spaced rays". And under remarks, Bukry continues: "The long slender bifurcation at the end of the rays and the prominent central knob in association with the long slender rays combine to produce the diagnostic appearance of the species".

Name: Zone CNM8 - Calcidiscus premacintyrei Top Zone 
Definition: Biostratigraphic interval between the Top of S.heteromorphus and the Top of continuous nominate taxon $C$.premacintyrei.

Reference section: ODP Site 926 (western tropical Atlantic Ocean)

Estimated age: $13.53 \mathrm{Ma}-12.57 \mathrm{Ma}$ (Fig. 2, Table 2)

Duration: 0.96 million years

Remarks: This zone corresponds to the lower parts of both Zone NN6 of Martini (1971) and Subzone CN5a of Okada and Bukry (1980).

Remarks on assemblages: The final part of the range of Calcidiscus premacintyrei is shown in Figure 8. Cyclicargolithus floridanus sharply decreases in abundance, while Reticulofenestra pseudoumbilicus and Triquetrorhabdulus rugosus begin to occur continously within this biostratigraphic interval. Specimens belonging to the Discoaster exilis group prevail within the Discoaster assemblages of the biozone.

\section{Name: Zone CNM9 - Discoaster variabilis Partial} Range Zone

Definition: Partial range of the nominate taxon between the Top of common C.premacintyrei and the Base of common Discoaster kugleri.

Reference section: ODP Site 926 (western tropical Atlantic Ocean)

Estimated age: $12.57 \mathrm{Ma}-11.88 \mathrm{Ma}$ (Fig. 2, Table 2)

Duration: 0.68 million years

Remarks: This zone corresponds to the upper parts of both Zone NN6 of Martini (1971) and Subzone CN5a of Okada and Bukry (1980).

Remarks on assemblages: The successive disappearances of Coronocyclus nitescens, Cyclicargolithus floridanus, and Triquetrorhabdulus serratus, occur within this biozone, whereas Calcidiscus macintyrei gradually increases in abundance.

Name: Zone CNM10 - Discoaster kugleri Total Range Zone

Definition: Biostratigraphic interval characterised by the total range of common nominate taxon D. kugleri. Reference section: ODP Site 926 (western tropical Atlantic Ocean)

Estimated age: 11.88 Ma-11.60 Ma (Fig.2, Table 2)

Duration: 0.28 million years

Remarks: This zone corresponds to the lowermost parts of both Zone NN7 of Martini (1971) and Subzone CN5b of Okada and Bukry (1980).

Remarks on assemblages: Among the Discoaster assemblages, six-ray stubby forms prevail, including D. kugleri, Discoaster musicus and Discoaster bollii.
The interval of common and continuous presence of D.kugleri has been observed in the tropical Pacific, mid-latitude northern and tropical Atlantic, and in the Mediterranean (Raffi et al. 1995, Backman and Raffi 1997, Hilgen et al. 2003).

\section{Name: Zone CNM11 - Discoaster exilis Partial Range} Zone

Definition: Partial range of the nominate taxon between the Top of common D. kugleri and the Base of Catinaster coalitus.

Reference section: ODP Site 926 (western tropical Atlantic Ocean)

Estimated age: $11.60 \mathrm{Ma}-10.79 \mathrm{Ma}$ (Fig. 2, Table 2) Duration: 0.81 million years

Remarks: This zone encompasses the upper $80 \%$ of both Zone NN7 of Martini (1971) and Subzone CN5b of Okada and Bukry (1980).

Remarks on assemblages: In the tropical Atlantic and the Mediterranean, Coccolithus miopelagicus disappears within upper CNM11. In the tropical Pacific, however, this species disappears within Zone CNM12, about 0.33 million years later. In the Mediterranean sections, the disappearance of representatives of small helicoliths, such as H.walbersdorfensis and Helicosphaera stalis, occurs within this biostratigraphic interval and provides biohorizons useful for regional biostratigraphy (Fornaciari et al. 1996).

Name: Zone CNM12 - Catinaster coalitus Base Zone Definition: Biostratigraphic interval between the Base of the nominate taxon C.coalitus and the Base of Discoaster hamatus.

Reference section: ODP Site 926 (western tropical Atlantic Ocean)

Estimated age: 10.79 Ma-10.49 Ma (Fig. 2, Table 2) Duration: 0.30 million years

Remarks: This zone corresponds to Zones NN8 of Martini (1971) and CN6 of Okada and Bukry (1980).

Remarks on assemblages: This short biostratigraphic interval marks the beginning of a series of subsequent appearances and extinctions of taxa, occurring troughout the late Miocene. It is characterised by the appearance of the first star-shaped asteroliths with pointed slender rays, namely Discoaster brouweri (6 rays) and Discoaster bellus (5 rays), and the presence of Discoaster calcaris. The genus Catinaster evolves within the biozone, whereas D. exilis disappears in its upper part.

Name: Zone CNM13 - Discoaster hamatus Total Range Zone 
Definition: Biostratigraphic interval characterised by the total range of the nominate taxon D. hamatus. Reference section: ODP Site 926 (western tropical Atlantic Ocean)

Estimated age: 10.49 Ma-9.65 Ma (Fig.2, Table 2)

Duration: 0.84 million years

Remarks: This zone corresponds to Zones NN9 of Martini (1971) and CN7 of Okada and Bukry (1980).

Remarks on assemblages: Shortly after the appearance of the nominate taxon D.hamatus, the six-rayed Discoaster neohamatus occurs. Discoaster bollii, C.coalitus and Catinaster calyculus disappear close to the top of the biozone.

Name: Zone CNM14 - Reticulofenestra pseudoumbilicus Partial Range Zone*

Definition: Partial range of the nominate taxon between the Top of D.hamatus and the Base of the interval of absence (Ba) of R.pseudoumbilicus.

Reference section: ODP Site 926 (western tropical Atlantic Ocean)

Estimated age: $9.65 \mathrm{Ma}-8.80 \mathrm{Ma}$ (Fig. 2, Table 2)

Duration: 0.85 million years

Remarks: This zone corresponds to the lower parts of Zone NN10 of Martini (1971) and Zone CN8 of Okada and Bukry (1980), respectively. Bukry (1978) used the appearance of both Discoaster neorectus and Discoaster loeblichii to define the top of the Discoaster bellus Subzone (top of CN8a). Among the adjacent biohorizons (Base D.loeblichii, Base D.neorectus, or Base Discoaster pentaradiatus) the Base of absence interval (Ba) of R.pseudoumbilicus is here considered to represent a more useful criterion for zonal boundary definition.

Remarks on assemblages: Minylitha convallis and Discoaster pentaradiatus appear within this biozone. *The use of the Ba concept for defining the top of this biozone differs from the strict definition of a Partial Range Zone as presented by Wade et al. (2011).

Name: Zone CNM15 - Discoaster bellus Base Zone* Definition: Biostratigraphic interval between the Base of the interval of absence of R.pseudoumbilicus and the Base of Discoaster berggrenii.

Reference section: ODP Site 926 (western tropical Atlantic Ocean)

Estimated age: $8.80 \mathrm{Ma}-8.20 \mathrm{Ma}$ (Fig. 2, Table 2)

Duration: 0.60 million years

Remarks: This zone corresponds to the upper parts of Zone NN10 of Martini (1971) and Zone CN8 of Okada and Bukry (1980), respectively. *The use of the
Base absence concept for definition of the base of this biozone differs from the strict definition of a Base Zone as presented by Wade et al. (2011).

Remarks on assemblages: The interval of almost total absence of R.pseudoumbilicus in upper Miocene sediments (the so-called "R.pseudoumbilicus paracme") has been observed in different ocean basins, from the tropical Indian, Pacific and Atlantic oceans to the Mediterranean (Rio et al. 1990b, Gartner 1992, Takayama 1993, Young 1990, Raffi and Flores 1995 Backman and Raffi 1997, Raffi et al.2003). Discoaster bellus and transitional forms between this species and Discoaster berggrenii occur within the biozone. This biozone also holds, e.g., in the tropical Pacific Ocean, the short-ranging Discoaster loeblichii and Discoaster neorectus, which Bukry (1978) used in his biozonation.

Name: Zone CNM16 - Discoaster berggrenii Base Zone

Definition: Biostratigraphic interval between the Base of the nominate taxon D.berggrenii and the Base of Amaurolithus primus.

Reference section: ODP Site 926 (western tropical Atlantic Ocean)

Estimated age: 8.20 Ma-7.39 Ma (Fig. 2, Table 2)

Duration: 0.81 million years

Remarks: This zone corresponds to the lower part of Zone NN11 of Martini (1971) and Subzone CN9a of Okada and Bukry (1980).

Remarks on assemblages: Discoaster quinqueramus appears just after the nominate taxon D.berggrenii and, with Discoaster surculus, characterises the Discoaster assemblages. Minylitha convallis disappears within this biozone.

Name: Zone CNM17 - Amaurolithus primus Base Zone

Definition: Biostratigraphic interval between the Base of the nominate taxon Amaurolithus primus and the Base of Nicklithus amplificus.

Reference section: ODP Site 926 (western tropical Atlantic Ocean)

Estimated age: 7.39 Ma-6.82 Ma (Fig. 2, Table 2)

Duration: 0.57 million years

Remarks: This zone corresponds to the middle part of Zone NN11 of Martini (1971) and to Subzone CN9b of Okada and Bukry (1980).

Remarks on assemblages: The beginning of the late Neogene horseshoe-shaped nannolith composite lineage (Amaurolithus - Nicklithus - Ceratolithus) marks 
the Base of this biozone, by the genus Amaurolithus evolving from Triquetrorhabdulus rugosus (Raffi et al. 1998). The appearance of Amaurolithus primus is closely followed by Amaurolithus delicatus. The interval of absence of R.pseudoumbilicus ends within this biozone (Ta R.pseudoumbilicus biohorizon in Fig. 2).

\section{Name: Zone CNM18 - Nicklithus amplificus Total Range Zone}

Definition: Biostratigraphic interval characterised by the total range of the nominate taxon N.amplificus.

Reference section: ODP Site 926 (western tropical Atlantic Ocean)

Estimated age: $6.82 \mathrm{Ma}-5.98 \mathrm{Ma}$ (Fig. 2, Table 2)

Duration: 0.83 million years

Remarks: This zone corresponds to an interval in the upper part of Zone NN11 of Martini (1971), and to the middle part of Subzone CN9b of Okada and Bukry (1980).

Remarks on assemblages: The short range of N.amplificus, bracketing Chron C3An, shows isochrony among tropical locations (Krijgsman et al. 1999). Amaurolithus primus, A.delicatus, and related transitional forms, characterise the nannofossil assemblages of this biozone.

\section{Name: Zone CNM19 - Discoaster quinqueramus Top Zone}

Definition: Biostratigraphic interval between the Top of N.amplificus and the Top of the nominate taxon D. quinqueramus.

Reference section: ODP Site 926 (western tropical Atlantic Ocean)

Estimated age: $5.98 \mathrm{Ma}-5.53 \mathrm{Ma}$ (Fig. 2, Table 2)

Duration: 0.45 million years

Remarks: This zone corresponds to the uppermost parts of Zone NN11 of Martini (1971) and Subzone CN9b of Okada and Bukry (1980), respectively.

Remarks on assemblages: Discoaster quinqueramus is a major component of the Discoaster assemblages in the uppermost Miocene interval, where it gradually replaces D. berggrenii. Transitional forms between the two species are frequent in this biozone, together with D.pentaradiatus, D. surculus, D.variabilis, and very large $(>30 \mu \mathrm{m})$ specimens of D.brouweri.

Name: Zone CNM20 - Triquetrorhabdulus rugosus Partial Range Zone

Definition: Partial range of the nominate taxon between the Top of D.quinqueramus and the Base of C.acutus.
Reference section: ODP Site 926 (western tropical Atlantic Ocean)

Estimated age: 5.53 Ma-5.36 Ma (Fig. 2, Table 2)

Duration: 0.17 million years

Remarks: This zone corresponds to the lowermost part of Zone NN12 of Martini (1971) and to Subzone CN10a of Okada and Bukry (1980).

Remarks on assemblages: Horseshoe-shaped nannoliths of the genus Ceratolithus evolve within this biostratigraphic interval, branching from T.rugosus (Raffi et al. 1998). Different species of the Ceratolithus lineage characterise the nannofossil assemblages in the lower Pliocene interval.

\section{Biozone definitions in the Pliocene-Pleistocene-Recent interval}

The definitions of the CNPL biozones are summarized in Table 3. Age estimates of zonal boundary markers and additional biohorizons in the PliocenePleistocene interval are summarized in Table 4. The average error of age estimates for the 27 PliocenePleistocene biohorizons is \pm 0.007 million years, as deduced from Table 4 (depth uncertainty divided by sedimentation rate). An overview of the CNPL zonation in a chronostratigraphic context, and comparison with Okada and Bukry's (1980) and Martini's (1971) Pliocene-Pleistocene zonations, is shown in Figure 9.

Name: Zone CNPL1 - Ceratolithus acutus Taxon Range Zone

Definition: Biostratigraphic interval characterised by the total range of the nominate taxon C.acutus.

Reference section: ODP Site 926 (western tropical Atlantic Ocean)

Estimated age: 5.36 Ma-5.05 Ma (Fig.9, Table 4)

Duration: 0.31 million years

Remarks: This zone corresponds approximately to the upper part of Zone NN12 of Martini (1971), who used the appearance of Ceratolithus rugosus to define Base NN12. This zone corresponds to Subzone CN10b of Okada and Bukry (1980), although Bukry (1978) used four taxa to define the subzonal boundaries which were subsequently employed by Okada and Bukry (1980): its base by the appearance of C.acutus and the disappearance of Triquetrorhabdulus rugosus, and its top by the disappearance of C.acutus and the appear- 
ance of C.rugosus. These two pairs of bioevents are separated in time by $30 \mathrm{ka}$ (top Subzone CN10b) and 130 ka (base Subzone CN10b) (Table 2), respectively. The Miocene-Pliocene boundary at 5.332 Ma (Lourens et al. 2004) falls shortly (28 ka) after the onset of Zone CNPL1.

Remarks on assemblages: Within this biozone, the peculiar species Ceratolithus atlanticus and Ceratolithus larrymayeri (Raffi et al. 1998) occur concomi- tantly with the disappearance of T.rugosus, in a short distinct interval that precedes the appearance of Ceratolithus rugosus.

Name: Zone CNPL2 - Sphenolitus neoabies Partial Range Zone

Definition: Partial range of the nominate taxon between the Top of C.acutus and the Base of common Discoaster asymmetricus.

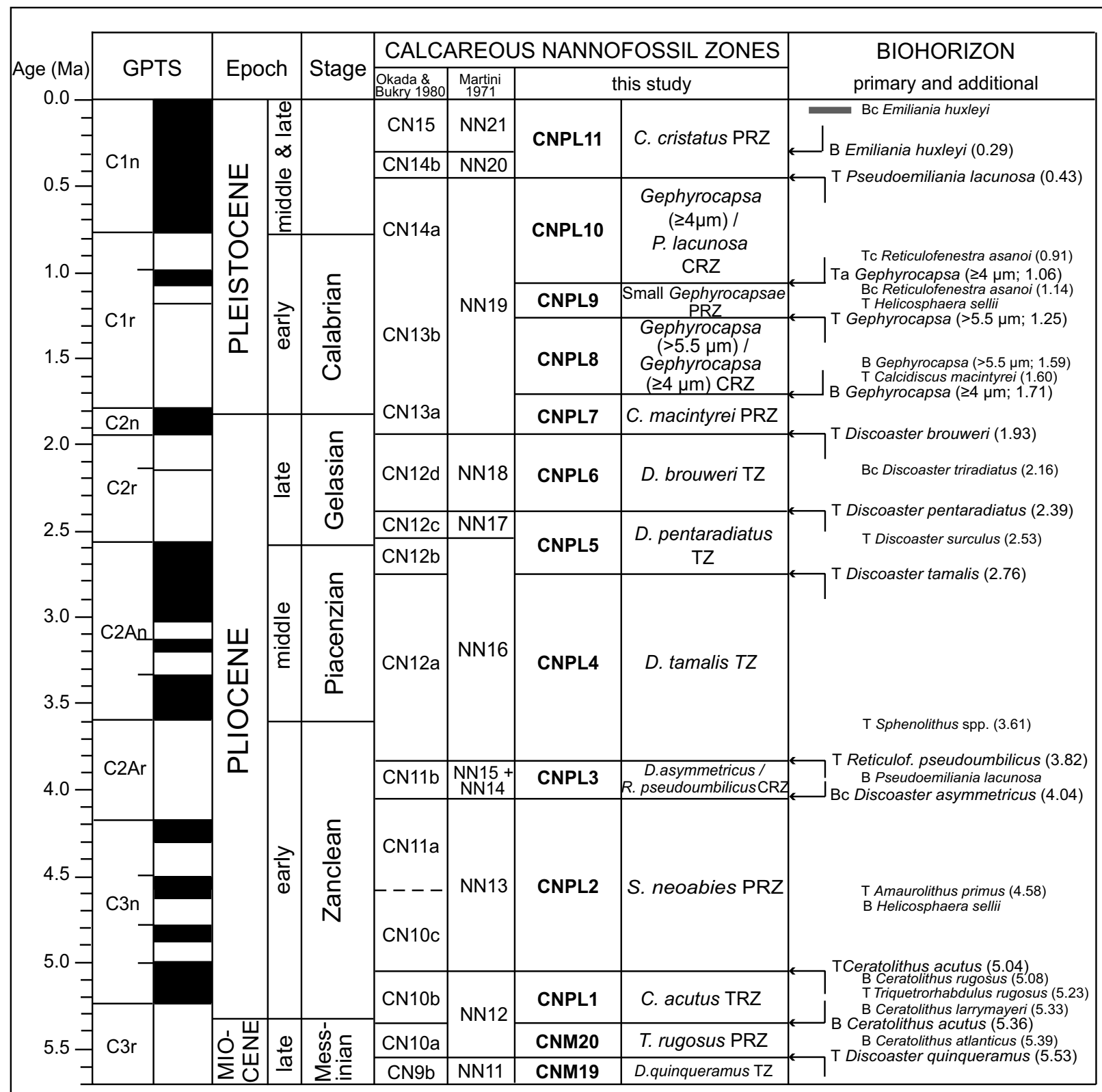

Fig. 9. Pliocene and Pleistocene biozones and biohorizons plotted versus "standard" zonations (Okada and Bukry 1980, Martini 1971) and the Geomagnetic Polarity Time Scale (GPTS; Lourens et al. 2004). Abbreviations are explained in the text. Middle and late Pleistocene stages are not yet formally defined. Bc Emiliania huxleyi is time transgressive (Thierstein et al. 1977), and marked with an interval rather than a line. 
Table 3 Biohorizons used for definitions of Pliocene and Pleistocene biozones.

\begin{tabular}{|c|c|c|c|c|c|}
\hline Marker Taxon for Base of Zone & Type of Event & Marker Taxon for Top of Zone & Type of event & Biozone* & Code \\
\hline Pseudoemiliania lacunosa & Top & (The Recent) & $\mathrm{n} / \mathrm{a}$ & C. cristatus PRZ & CNPL11 \\
\hline Gephyrocapsa spp. $\geq 4 \mu \mathrm{m}$ & Top absence & Pseudoemiliania lacunosa & Top & Gephyrocapsa $(\geq 4 \mu \mathrm{m}) /$ P. lacunosa PRZ & CNPL10 \\
\hline Gephyrocapsa spp. $>5.5 \mu \mathrm{m}$ & Base & Gephyrocapsa spp. $\geq 4 \mu \mathrm{m}$ & Top absence & Small Gephyrocapsa PRZ & CNPL9 \\
\hline Gephyrocapsa spp. $\geq 4 \mu \mathrm{m}$ & Base & Gephyrocapsa spp. $>5.5 \mu \mathrm{m}$ & Top & Gephyrocapsa $(>5.5 \mu \mathrm{m}) /$ Gephyrocaps $a(\geq 4 \mu \mathrm{m}) \mathrm{CRZ}$ & CNPL8 \\
\hline Discoaster brouweri & Top & Gephyrocapsa spp. $\geq 4 \mu \mathrm{m}$ & Base & C. macintyrei PRZ & CNPL7 \\
\hline Discoaster pentaradiatus & Top & Discoaster brouweri & Top & D. brouweri $\mathrm{TZ}$ & CNPL6 \\
\hline Discoaster tamalis & Top & Discoaster pentaradiatus & Top & D. pentaradiatus $\mathrm{TZ}$ & CNPL5 \\
\hline Reticulofenestra pseudoumbilicus & Top & Discoaster tamalis & Top & D. tamalis TZ & CNPL4 \\
\hline Discoaster asymmetricus & Base common & Reticulofenestra pseudoumbilicus & Top & D. asymmetricus / R. pseudoumbilicus CRZ & CNPL3 \\
\hline Ceratolithus acutus & Top & Discoaster asymmetricus & Base common & S. neoabies PRZ & CNPL2 \\
\hline Ceratolithus acutus & Base & Ceratolithus acutus & Top & C. acutus TRZ & CNPL1 \\
\hline
\end{tabular}

*Taxon Range Zone (TRZ), Concurrent Range Zone (CRZ), Base Zone (BZ), Top Zone (TZ), Partial Range Zone (PRZ)

Table 4 Age estimates of biohorizons. Biohorizons defining biozone boundaries are marked in bold. mcd - meters composite depth. Acronyms used for depth and age columns are: VG90 - Vergnaud Grazzini et al. 1990; LR05 - Lisiecki and Raymo 2005; RAY89 - Raymo et al. 1989; SC97 - Shackleton and Crowhurst 1997.

\begin{tabular}{|c|c|c|c|c|c|c|c|c|c|c|c|}
\hline \multirow[b]{2}{*}{ Event } & \multirow[b]{2}{*}{ Species } & \multirow[b]{2}{*}{ Reference } & \multirow{2}{*}{$\begin{array}{c}\text { Depth } \\
\text { med } \\
\end{array}$} & \multirow[b]{2}{*}{$\pm \mathbf{m}$} & \multirow{2}{*}{\begin{tabular}{|c|} 
DSDP/ODP \\
Hole \\
\end{tabular}} & \multicolumn{2}{|c|}{ Interpolation between } & \multicolumn{2}{|c|}{ Interpolation between } & \multirow{2}{*}{$\begin{array}{l}\text { Rate } \\
\mathrm{m} / \mathbf{m y r} \\
\end{array}$} & \multirow{2}{*}{$\begin{array}{l}\text { Age } \\
\text { Ma } \\
\end{array}$} \\
\hline & & & & & & Upper Depth & Lower Depth & Younger Age & Older Age & & \\
\hline \multirow[b]{2}{*}{ B } & \multirow[b]{2}{*}{ E. huxleyi } & \multirow[b]{2}{*}{ Rio et al., 1990} & \multirow[b]{2}{*}{15.60} & \multirow[b]{2}{*}{0.30} & \multirow[b]{2}{*}{$653 \mathrm{~A}$} & VG90 $(7 / 8)^{1}$ & VG90 $(8 / 9)^{1}$ & LR05 & LR05 & \multirow[b]{2}{*}{0.1} & \multirow[b]{2}{*}{0.29} \\
\hline & & & & & & 12.50 & 16.50 & 243 & 300 & & \\
\hline \multirow{5}{*}{$\begin{array}{c}\mathrm{T} \\
\mathrm{T} \\
\mathrm{Ta} \\
\mathrm{Bc}\end{array}$} & \multirow{5}{*}{$\begin{array}{l}\text { P. lacunosa } \\
\text { R. asanoi } \\
\text { Gephyrocapsa }(\geq \mathbf{4} \boldsymbol{\mu m}) \\
\text { R. asanoi }\end{array}$} & \multirow[b]{2}{*}{ This study } & \multirow[b]{2}{*}{16.61} & \multirow[b]{2}{*}{0.05} & \multirow[b]{2}{*}{$926 \mathrm{C}$} & SC97 & SC97 & SC97 & SC97 & \multirow[b]{2}{*}{45.0} & \multirow[b]{2}{*}{0.43} \\
\hline & & & & & & 16.05 & 16.95 & 0.42 & 0.44 & & \\
\hline & & Raffi, 2002 & 30.52 & 0.15 & $926 \mathrm{C}$ & 29.90 & 31.15 & 0.90 & 0.93 & 41.7 & 0.91 \\
\hline & & Raffi, 2002 & 34.58 & 0.05 & 926B & 34.50 & 35.20 & 1.06 & 1.08 & 35.0 & 1.06 \\
\hline & & Raffi, 2002 & 36.66 & 0.05 & $926 \mathrm{C}$ & 36.60 & 37.55 & 1.14 & 1.18 & 23.7 & 1.14 \\
\hline & & & & & & RAY89 (36/37) & RAY89 (37/38) & LR05 & LR05 & & \\
\hline $\mathrm{T}$ & H. sellii (Atlantic) & Raffi et al., 1993 & 50.60 & 0.23 & 607 & 49.81 & 50.63 & 1.215 & 1.244 & 28.3 & 1.24 \\
\hline & & & & & & SC97 & SC97 & SC97 & SC97 & & \\
\hline $\mathbf{T}$ & Gephyrocapsa $(>5.5 \mu \mathrm{m})$ & Raffi, 2002 & 39.36 & 0.05 & $926 \mathrm{C}$ & 38.55 & 39.50 & 1.22 & 1.25 & 31.7 & 1.25 \\
\hline B & Gephyrocapsa $(>5.5 \mu \mathrm{m})$ & Raffi, 2002 & 50.00 & 0.25 & $926 \mathrm{C}$ & 48.80 & 50.30 & 1.56 & 1.60 & 37.5 & 1.59 \\
\hline $\mathrm{T}$ & C. macintyrei & Raffi, 2002 & 50.40 & 0.05 & $926 \mathrm{C}$ & 50.30 & 51.55 & 1.60 & 1.63 & 41.7 & 1.60 \\
\hline B & Gephyrocapsa $(\geq \mathbf{4} \mu \mathrm{m})$ & Raffi, 2002 & 53.85 & 0.10 & 926B & 53.75 & 54.45 & 1.71 & 1.73 & 35.0 & 1.71 \\
\hline $\mathbf{T}$ & D. brouweri & Curry, Shackleton et al., 1995 & 60.53 & 0.20 & $926 \mathrm{~A}$ & 60.15 & 61.35 & 1.92 & 1.96 & 30.0 & 1.93 \\
\hline $\mathrm{Bc}$ & D. triradiatus & Curry, Shackleton et al., 1995 & 66.73 & 0.35 & $926 \mathrm{~A}$ & 66.05 & 67.05 & 2.13 & 2.18 & 20.0 & 2.16 \\
\hline $\mathbf{T}$ & D. pentaradiatus & Curry, Shackleton et al., 1995 & 73.86 & 0.47 & 926A & 73.75 & 74.00 & 2.38 & 2.41 & 8.3 & 2.39 \\
\hline $\mathrm{T}$ & D. surculus & Curry, Shackleton et al., 1995 & 78.87 & 0.25 & $926 \mathrm{C}$ & 78.70 & 81.35 & 2.53 & 2.60 & 37.9 & 2.53 \\
\hline $\mathbf{T}$ & D. tamalis & Curry, Shackleton et al., 1995 & 86.83 & 0.25 & $926 \mathrm{C}$ & 85.50 & 87.10 & 2.72 & 2.77 & 32.0 & 2.76 \\
\hline & & & & & & Heiko & Pälike, personal c & ommunication, & & & \\
\hline $\mathrm{T}$ & Sphenolithus spp. & Curry, Shackleton et al., 1995 & 117.18 & 0.38 & 925B & 116.09 & 117.40 & 3.58 & 3.62 & 35.4 & 3.61 \\
\hline & & & & & & SC97 & SC97 & SC97 & SC97 & & \\
\hline $\mathbf{T}$ & R.pseudoumbilicus & Curry, Shackleton et al., 1995 & 118.36 & 0.20 & $926 \mathrm{~A}$ & 118.10 & 119.60 & 3.81 & 3.85 & 37.5 & 3.82 \\
\hline $\mathbf{B c}$ & D. asymmetricus & This study & 125.78 & 0.10 & $926 \mathrm{C}$ & 124.95 & 125.95 & 4.02 & 4.04 & 50.0 & 4.04 \\
\hline $\mathbf{T}$ & C. acutus & Backman \& Raffi, 1997 & 154.82 & 0.05 & 926B & 154.70 & 155.35 & 5.04 & 5.06 & 32.5 & 5.04 \\
\hline B & C. rugosus & Backman \& Raffi, 1997 & 155.73 & 0.05 & $926 \mathrm{C}$ & 155.70 & 156.25 & 5.08 & 5.10 & 27.5 & 5.08 \\
\hline $\mathrm{T}$ & C. atlanticus & Backman \& Raffi, 1997 & 158.96 & 0.05 & $926 \mathrm{~A}$ & 158.91 & 159.91 & 5.22 & 5.27 & 20.0 & 5.22 \\
\hline $\mathrm{T}$ & T. rugosus & Backman \& Raffi, 1997 & 159.01 & 0.50 & 926A & 158.91 & 159.91 & 5.22 & 5.27 & 20.0 & 5.23 \\
\hline $\mathrm{T}$ & C. larrymayeri & Backman \& Raffi, 1997 & 159.76 & 0.05 & $926 \mathrm{~A}$ & 158.91 & 159.91 & 5.22 & 5.27 & 20.0 & 5.26 \\
\hline B & C. larrymayeri & Backman \& Raffi, 1997 & 161.45 & 0.05 & $926 \mathrm{~A}$ & 161.21 & 161.71 & 5.32 & 5.34 & 25.0 & 5.33 \\
\hline B & C. acutus & Backman \& Raffi, 1997 & 162.16 & 0.05 & $926 \mathrm{~A}$ & 161.71 & 162.71 & 5.34 & 5.39 & 20.0 & 5.36 \\
\hline B & C. atlanticus & Backman \& Raffi, 1997 & 162.66 & 0.05 & $926 \mathrm{~A}$ & 161.71 & 162.71 & 5.34 & 5.39 & 20.0 & 5.39 \\
\hline $\mathbf{T}$ & D. quinqueramus & Backman \& Raffi, 1997 & 165.49 & 0.10 & $926 \mathrm{C}$ & 165.46 & 165.91 & 5.53 & 5.55 & 22.5 & 5.53 \\
\hline
\end{tabular}

1 Numbers in brackets refer to Marine Isotope Stage (MIS) boundaries. 
Reference section: ODP Site 926 (western tropical Atlantic Ocean)

Estimated age: 5.05 Ma-4.04 Ma (Fig. 9, Table 4)

Duration: 1.01 million years

Remarks: Taxonomic ambiguities of the Amaurolithus - Ceratolithus lineage during the early 1970s (Gartner 1969, Gartner and Bukry 1975) in combination with low abundances of the critical biohorizons make the lower Pliocene zonations of Martini (1971) and Bukry (1973a) problematic. Martini used Base Discoaster asymmetricus and Top "Ceratolithus tricorniculatus" for subdivision of the NN13/NN14 and NN14/NN15 zonal boundaries, respectively. Bukry used two biohorizons for subdivision of Subzone CN10c/CN11a (Top "Ceratolithus primus", Top "Ceratolithus tricorniculatus"), and the "Beginning of acme" of D.asymmetricus for subdivision of Subzones $\mathrm{CN} 11 \mathrm{a} / \mathrm{CN} 11 \mathrm{~b}$ without quantifying the "acme" concept. The appearance interval of D.asymmetricus as well as the disapperance intervals of A.primus and A.tricorniculatus are characterised by low and discontinuous occurrences. As a consequence, these biohorizons are still poorly calibrated to independent chronologies. Taken together, these factors make them less suitable for zonal boundary definitions. We have investigated the abundance behavior of D.asymmetricus at ODP Site 926 (Fig. 10), and suggest that the level where D.asymmetricus increases to $>10 \%$ relative to its ancestor taxon D.brouweri represents a suitable criterion for defining the Base of common $(\mathrm{Bc})$ D.asymmetricus. This occurs at $4.04 \mathrm{Ma}$.

Name: Zone CNPL3 - Discoaster asymmetricus/ Reticulofenestra pseudoumbilicus Concurrent Range Zone

Definition: Concurrent range of the nominate taxa between the Base of common D.asymmetricus and the Top of R.pseudoumbilicus.

Reference section: ODP Site 926 (western tropical Atlantic Ocean)

Estimated age: 4.04 Ma-3.81 Ma (Fig.9, Table 4)

Duration: 0.23 million years

Remarks: This zone encompasses Zones NN14 and NN15 of Martini (1971), and Subzone CN11b of Okada and Bukry (1980). The Top of R.pseudoumbilicus shows synchrony across the low latitude Atlantic Ocean (Gibbs et al. 2005).

Remarks on assemblages: In the upper part of this biostratigraphic interval, the first, small and rare specimens of Pseudoemiliania lacunosa begin to occur and rare specimens of Discoaster tamalis begin to occur more consistently. The last representative of the genus Amaurolithus, A.delicatus, disappears within this biozone. Its disappearance horizon may be blurred for reasons pointed out by Raffi and Flores (1995): "Misidentification occurs in samples that contain nannofossils with calcite overgrowth and when specimens of different Amaurolithus and Ceratolithus species possess intergrade morphologic features. This is the case in most of the lower Pliocene sequences recovered during Leg 138. Ceratolithid species are irregularly distributed and are not easily differentiated because of the presence of overgrowth and intergrade morphotypes."

Name: Zone CNPL4 - Discoaster tamalis Top Zone

Definition: Biostratigraphic interval between the Top of R.pseudoumbilicus and the Top of the nominate taxon D.tamalis.

Reference section: ODP Site 926 (western tropical Atlantic Ocean)

Estimated age: $3.81 \mathrm{Ma}-2.76 \mathrm{Ma}$ (Fig.9, Table 4)

Duration: 1.05 million years

Remarks: This zone corresponds to part of Zone NN16 of Martini (1971) and to Subzone CN12a of Okada and Bukry (1980). Raffi and Flores (1995, table 2) proposed an identical age estimate (2.76 Ma) for the disappearance of D.tamalis from the low latitude eastern Pacific Ocean, whereas Shackleton et al.

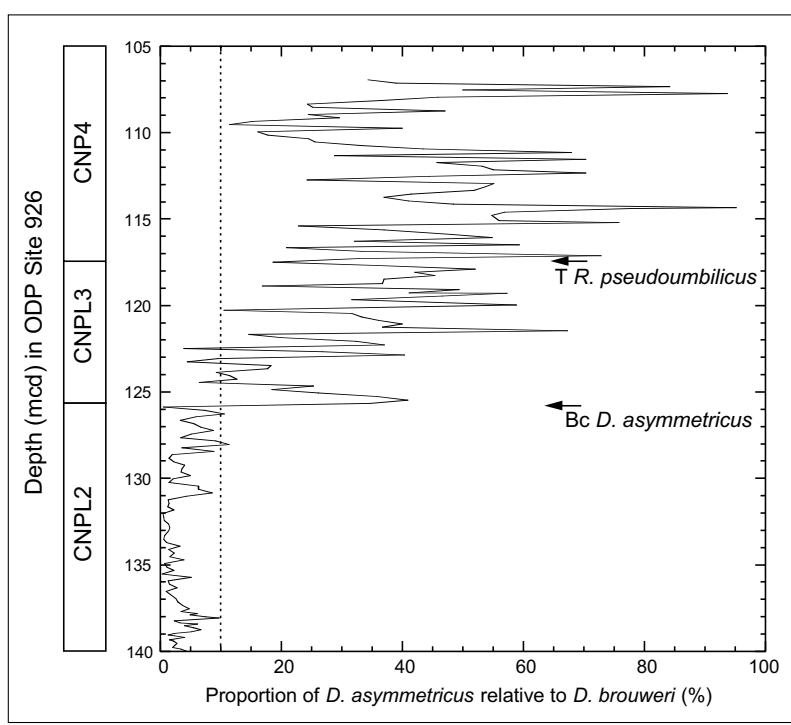

Fig. 10. Increase in relative abundance of D.asymmetricus relative to its ancestor species $D$. brouweri. The $10 \%$ limit is used to define the $\mathrm{Bc} D$.asymmetricus biohorizon and the CNPL2/CNPL3 biozone boundary. The T R.pseudoumbilicus biohorizon defines the CNPL3/CNPL4 biozone boundary. 
(1995, tables 4, 7) indicated ages ranging from 3.01 Ma (Site 846) to $2.70 \mathrm{Ma}$ (Site 848) and a "best estimate" of $2.78 \mathrm{Ma}$.

Remarks on assemblages: The genus Sphenolithus, represented by the species S.abies and S.neoabies, disappears about 0.2 million years after the onset of this biozone.

\section{Name: Zone CNPL5 - Discoaster pentaradiatus Top Zone}

Definition: Biostratigraphic interval between the Top of D.tamalis and the Top of the nominate taxon D.pentaradiatus.

Reference section: ODP Site 926 (western tropical Atlantic Ocean)

Estimated age: 2.76 Ma-2.39 Ma (Fig.9, Table 4)

Duration: 0.37 million years

Remarks: This zone includes the uppermost part of Zone NN16 and Zone NN17 of Martini (1971) and Subzones CN12b and CN12c of Okada and Bukry (1980). Zone NN17 was established from findings of rare discoasters in five samples from two core sections characterised by severe drilling disturbance (Winterer, Riedel et al. 1971, p. 143) at DSDP Site 62 (Martini 1971, Martini and Worsley 1971).

Remarks on assemblages: The disappearance of D. surculus occurs within the biozone. According to Bukry (1973a), "The disappearance of D. surculus typically precedes $D$.pentaradiatus, but the interval is short and D.surculus survives diagenetic changes and reworking better than $D$. pentaradiatus. Therefore, for practical application their disappearances are considered similar". Subsequently, when Bukry (1975) established the D.surculus Subzone, the interval between the successive disappearances of D.tamalis and D. surculus, he remarked however that "Sampling interval, sedimentation rate and degree of reworking may determine whether this brief subzonal interval can be identified". The biostratigraphic distance between the successive disappearances of D.surculus and D. pentaradiatus (D.pentaradiatus Subzone-CN12c) is even briefer, and Bukry (1975, p.678) did not distinguish the D.pentaradiatus Subzone in the investigated DSDP Leg 32 sites. Our experience is similar to Bukry's in that this short biostratigraphic interval often is difficult to distinguish consistently and, at some locations, the two taxa seem to disappear simultaneously. Here, we hence do not employ Top D. surculus for definition of a zonal boundary.

Name: Zone CNPL6 - Discoaster brouweri Top Zone
Definition: Biostratigraphic interval between the Top of $D$.pentaradiatus and the Top of the nominate taxon D.brouweri.

Reference section: ODP Site 926 (western tropical Atlantic Ocean)

Estimated age: 2.39 Ma-1.93 Ma (Fig. 9, Table 4)

Duration: 0.46 million years

Remarks: This zone corresponds to Zone NN18 of Martini (1971) and to Subzone CN12d of Okada and Bukry (1980).

Remarks on assemblages: The three-rayed morphotype of D.brouweri, D.triradiatus, shows a proportional increase relative to D.brouweri at about 0.23 million years prior to their mutual disappearance and extinction of the genus Discoaster at $1.93 \mathrm{Ma}$ (Backman and Shackleton, 1983), shortly after the onset of Subchron C2n (Olduvai) at 1.945 Ma. The genus Discoaster thus existed for about 57 million years, considering the evolutionary appearance of the first discoaster species, D. mohleri, at ca. 58.93 Ma (Agnini et al. 2007). Continuous occurrences of small $(<4 \mu \mathrm{m})$ specimens of the genus Gephyrocapsa are recorded in the upper part of Zone CNPL6.

Name: Zone CNPL7 - Calcidiscus macintyrei Partial Range Zone

Definition: Partial range of the nominate taxon between the Top of D. brouweri and the Base of Gephyrocapsa $(\geq 4 \mu \mathrm{m})$.

Reference section: ODP Site 926 (western tropical Atlantic Ocean)

Estimated age: 1.93 Ma-1.71 Ma (Fig.9, Table 4)

Duration: 0.22 million years

Remarks: This zone corresponds to the lowermost part of Zone NN19 of Martini (1971). Bukry (1973a) employed the successive appearances of Gephyrocapsa caribbeanica and G.oceanica to subdivide the interval between Top Discoaster brouweri and Top Pseudoemiliania lacunosa. Okada and Bukry (1980) codified the three resulting subzones as CN13a, $\mathrm{CN} 13 \mathrm{~b}$ and CN14a. A consequence of our different taxonomic approach with respect to the use of gephyrocapsids in Pleistocene biostratigraphy (see remarks under Zone CNPL8), compared to Bukry's use of members of this genus, is that Subzones CN13a, $\mathrm{CN} 13 \mathrm{~b}$ and $\mathrm{CN} 14 \mathrm{a}$ are not compatible with the fourfold subdivision we use for the identical biostratigraphic interval, from Zone CNPL7 through Zone CNPL10. There is hence no precise correspondence between the two zonal systems, despite the use of gephyrocapsids in both cases. 
Remarks on assemblages: An increase in abundance of small $(<4 \mu \mathrm{m})$ Gephyrocapsa specimens and $H$. sellii characterise this biostratigraphic interval.

Name: Zone CNPL8 - Gephyrocapsa (>5.5 $\mu \mathrm{m})$ / Gephyrocapsa $(\geq 4 \mu \mathrm{m})$ Concurrent Range Zone*

Definition: Biostratigraphic interval between the Base of the nominate taxon Gephyrocapsa $(\geq 4 \mu \mathrm{m})$ and the Top of Gephyrocapsa (>5.5 $\mu \mathrm{m})$.

Reference section: ODP Site 926 (western tropical Atlantic Ocean)

Estimated age: 1.71 Ma-1.25 Ma (Fig.9, Table 4)

Duration: 0.46 million years

Remarks: This zone corresponds to an interval in the lower part of Zone NN19 of Martini (1971). *The use of a taxon, or rather morphotype in this case, that appears within the biozone for definition of its top (Top Gephyrocapsa $>5.5 \mu \mathrm{m}$ ) differs from the strict concept of a Concurrent Range Zone by Wade et al. (2011). Remarks on assemblages: The rapid morphologic evolution of the genus Gephyrocapsa during the Pleistocene provides a series of biohorizons useful for improving the biostratigraphic resolution of the previous zonations of Martini (1971) and Okada and Bukry (1980). For reasons discussed by Raffi et al. (1993), we have adopted an informal taxonomic subdivision of Gephyrocapsa, based on placolith length. This approach has proven successful in terms of biostratigraphic usefulness in many regions, including the western and eastern Pacific Ocean, the Caribbean Sea, the Mediterranean and the North Atlantic. It follows that our zonal boundary definitions are not based on presence/absence of single taxa, but may include several gephyrocapsid taxa. For example, specimens ranging from $4.0 \mu \mathrm{m}$ to $5.5 \mu \mathrm{m}$ in placolith length include both Gephyrocapsa caribbeanica and Gephyrocapsa oceanica. Specimens $>5.5 \mu \mathrm{m}$ include Gephyrocapsa lumina, as well as G.oceanica sensu Bukry (1973b, p.678). Calcidiscus macintyrei disappears in the lower part of the biozone, just prior to the appearance of Gephyrocapsa spp. $>5.5 \mu \mathrm{m}$. The group of gephyrocapsid placoliths being 4.0 through $5.5 \mu \mathrm{m}$ in length is often referred to as "medium sized" in the literature. Here, it is referred to as Gephyrocapsa spp. $\geq 4 \mu \mathrm{m}$.

Name: Zone CNPL9 - Small Gephyrocapsa Partial Range Zone

Definition: Partial range of the nominate taxon between the Top of Gephyrocapsa $(>5.5 \mu \mathrm{m})$ and the reentrance of Gephyrocapsa ( $\geq 4 \mu \mathrm{m})$.
Reference section: ODP Site 926 (western tropical Atlantic Ocean)

Estimated age: 1.25 Ma-1.06 Ma (Fig. 9, Table 4)

Duration: 0.19 million years

Remarks: This zone corresponds to an interval within Zone NN19 of Martini (1971).

Remarks on assemblages: The interval of almost total absence of what we refer to as medium-sized (4.0$5.5 \mu \mathrm{m})$ and large $(>5.5 \mu \mathrm{m})$ Gephyrocapsa specimens (Rio 1982, Raffi et al. 1993) delineates the socalled "Small Gephyrocapsa Zone" of Gartner's (1977) Pleistocene zonation. This interval of absence has been observed in different oceanic basins (Gartner 1977, Rio 1982, Raffi et al. 1993, Wei 1993), and is characterised by a dominance of small Gephyrocapsa specimens and P. lacunosa in nannofossil assemblages. In the mid-latitude North Atlantic, Helicosphaera sellii disappears shortly after the onset of Zone CNPL9. Reticulofenestra asanoi appears in the upper part of this biozone.

Name: Zone CNPL10 - Gephyrocapsa ( $\geq 4 \mu \mathrm{m}) /$ Pseudoemiliania lacunosa Concurrent Range Zone

Definition: Concurrent range of the nominate taxa between the Top absence of Gephyrocapsa $(\geq 4 \mu \mathrm{m})$ and the Top of P.lacunosa.

Reference section: ODP Site 926 (western tropical Atlantic Ocean)

Estimated age: $1.06 \mathrm{Ma}-0.43 \mathrm{Ma}$ (Fig. 9, Table 4)

Duration: 0.63 million years

Remarks: This zone corresponds to the upper part of Zone NN19 of Martini (1971).

Remarks on assemblages: The Gephyrocapsa specimens that re-enter the stratigraphic record following the interval of near-total dominance of gephyrocapsids $<4 \mu \mathrm{m}$ are mostly medium-sized (4.0-5.5 $\mu \mathrm{m})$, whereas larger forms $(>5.5 \mu \mathrm{m})$ occur sporadically. The $\geq 4 \mu \mathrm{m}$ specimens that reaches prominence again, following the absence interval (Zone CNPL9), among the gephyrocapsid assemblages contain common to abundant Gephyrocapsa parallela (Hay and Beaudry 1973), with its characteristic wide central opening and its bridge nearly aligned with the elliptical placolith's short axis. Gephyrocapsa omega (Bukry 1973b) is a junior synonym of $G$. parallela. The medium-sized Reticulofenestra asanoi decrease in abundance prior to its extinction in the lower part of the biozone. Large specimens of P.lacunosa characterise its uppermost distribution range.

Name: Zone CNPL11 - Ceratolithus cristatus Partial Range Zone 
Definition: Partial range of the nominate taxon between the Top of P.lacunosa and the Recent.

Reference section: ODP Site 926 (western tropical Atlantic Ocean)

Estimated age: $0.43 \mathrm{Ma}-0.00 \mathrm{Ma}$ (Fig.9, Table 4)

Duration: 0.43 million years

Remarks: This zone includes Zones NN20 and NN21 of Martini (1971), and Subzone CN14b and Zone CN15 of Okada and Bukry (1980).

Remarks on assemblages: Emiliania huxleyi appears within this biostratigraphic interval, and increases in proportion relative to gephyrocapsids in the upper part of the biozone (Thierstein et al. 1977). Subsequent studies have confirmed the diachrony in this abundance cross-over, initially pointed out by Thierstein et al. (1977), spanning most of the latest glacial cycle (Jordan et al. 1996, Findley and Flores 2000, Villaneuva et al. 2002, Baumann and Freitag 2004).

\section{Summary}

The Miocene through Pleistocene biozonation presented here represents a basic biostratigraphic framework for relative dating of marine sediments using calcareous nannofossils. This new biozonation is an updated synthesis that relies on what Erlend Martini referred to as a "Standard [...] zonation", and the lowlatitude zonation provided by David Bukry. Our biozonation, however, includes several of the biohorizons they used for zonal boundary definitions that have proven to be reliable, besides several new biohorizons. We take into account the biostratigraphic data that we have produced over nearly three decades from chiefly low and middle latitudes in all three major ocean basins and the Mediterranean Sea region, derived by applying semi-quantitative methods on high resolution sampling sets from core material retrieved by the Ocean Drilling Program. Previously unpublished biostratigraphic data showing the abundance behaviour of some of the marker species are presented.

Age estimates for all biohorizons are presented, with calibration references for all individual biohorizons. In the Miocene through Pleistocene interval, the independent age control is chiefly provided by astronomically tuned cyclostratigraphies.

Thirty-one (31) biozones are established that span the past 23 million years, implying an average duration of about 0.74 million years for the biozones. The span of duration of indidvidual biozones however varies from 0.15 to 2.20 million years. Pliocene-Pleistocene zones have an average duration of 0.48 million years, whereas the average duration of Miocene biozones is 0.89 million years. The longest biozone, the Discoaster signus Concurrent Range Zone encompasses ca. $50 \%$ (2.20 million years) of the middle Miocene.

We employ a limited set of selected biohorizons in the new biozonation in order to maintain stability to the scheme and hence avoid introduction of subzones. Most of the new biozones, however, contains several additional biohorizons.

Acknowledgements. We acknowledge the importance of past support and continued inspiration provided by the late Nick Shackleton (1937-2006). This research used samples provided by the Integrated Ocean Drilling Program (IODP) sponsored by the U.S. National Science Foundation (NSF) and participating countries under management of Joint Oceanographic Institutions (JOI). This research has been made possible thanks to support from Stockholm University and the Swedish Research Council (JB), by the Università degli Studi "G. d'Annunzio" (IR), and the Università degli Studi di Padova (DR, EF). Reviews by Sherwood W. Wise, Jr. and an anynomous reviewer are gratefully acknowledged.

\section{References}

Agnini, C., Fornaciari, E., Raffi, I., Rio, D., Röhl, U., Westerhold, T., 2007. High-resolution nannofossil biochronology of middle Paleocene to early Eocene at ODP Site 1262: Implications for calcareous nannoplankton evolution. Marine Micropaleontology 64, 215-248. doi:10. 1016/j.marmicro.2007.05.003

Agnini, C., Fornaciari, E., Giusberti, L., Grandesso, P., Lanci, L., Luciani, V., Muttoni, G., Pälike, H., Rio, D., Spofforth, D.J.A., Stefani, C., 2011. Integrated biomagnetostratigraphy of the Alano section (NE Italy): A proposal for defining the middle-late Eocene boundary. GSA Bulletin 123, 841-872. doi:10.1130/B30158.1

Backman, J., Shackleton, N.J., 1983. Quantitative biochronology of Pliocene and Pleistocene calcareous nannofossils from the Atlantic, Indian and Pacific oceans. Marine Micropaleontology 8, 141-170.

Backman, J., Raffi, I., 1997. Calibration of Miocene nannofossil events to orbitally tuned cyclostratigraphies from Ceara Rise. In: Curry, W. B., Shackleton, N. J., Richter, C., Bralower, T. J., et al., Proceedings ODP Scientific Results 154 (Ocean Drilling Program, College Station, TX), 83-99. doi:10.2973/odp.proc.sr.154.101.1997

Baumann, K.-H., Freitag, T., 2004. Pleistocene fluctuations in the northern Benguela Current system as revealed by coccolith assemblages. Marine Micropaleontology 52, $195-215$. 
Berggren, W.A., Kent, D. V., van Couvering, J. A., 1985. Neogene geochronology and chronostratigraphy. In: Snelling, N.J., The chronology of the geological record: London, Geological Society of London Memoir 10, 211260.

Berggren, W.A., Kent, D.V., Swisher, C.C. III, Aubry, M.-P., 1995. A revised Cenozoic geochronology and chronostratigraphy. In: Berggren, W.A., Kent, D. V., Aubry, M.-P., Hardenbol, J., Geochronology, time scales and global stratigraphic correlation: A unified temporal framework for an historical geology. Spec. Publ. Soc. Econ. Paleontol. Mineral., 54, 29-212.

Berggren, W.A., Pearson, P. N., 2006. Tropical and subtropical planktonic foraminiferal zonation of the Eocene and Oligocene. In: Pearson, P. N., Olsson, R. K., Huber, B. T., Hemleben, C., Berggren, W. A. (Eds.), Cushman Foundation Special Publication 41, 29-40.

Bukry, D., 1971. Discoaster evolutionary trends. Micropaleontology 17, 43-52.

Bukry, D., 1973a. Low-latitude coccolith biostratigraphic zonation. In: Edgar, N.T., Saunders, J.B., et al., Initial Reports DSDP 15, Washington (U.S. Govt. Printing Office), 685-703. doi:10.2973/dsdp.proc.15.116.1973

Bukry, 1973b. Coccolith stratigraphy, eastern Equatorial Pacific, Leg 16 Deep Sea Drilling Project. In: van Andel, T.H., Heath, G. R., et al., Initial Reports DSDP 16, Washington (U.S. Govt. Printing Office), 653-711. doi:10. 2973/dsdp.proc.16.126.1973

Bukry, D., 1975. Coccolith and silicoflagellate stratigraphy, northwestern Pacific Ocean, Deep Sea Drilling Project Leg 32. In: Larson, R.L., Moberly, R., et al., Initial Reports DSDP 32, Washington (U.S. Govt. Printing Office), 677-701. doi:10.2973/dsdp.proc.32.124.1975

Bukry, D., 1978. Biostratigraphy of Cenozoic marine sediments by calcareous nannofossils. Micropaleontology 24, 44-60.

Bukry, D., Bramlette, M.N., 1970. Coccolith age determinations Leg 3, Deep Sea Drilling Project. In: Maxwell, A.E., et al., Initial Reports DSDP 3, Washington (U.S. Govt. Printing Office), 589-611. doi:10.2973/dsdp.proc. 3.118.1970

Curry, W. B., Shackleton, N. J., Richter, C., et al., 1995. Proceedings ODP, Initial Reports 154 (Ocean Drilling Program, College Station, TX), 1-1111. doi:10.2973/ odp.proc.ir.154.1995

Filewicz, M. V., 1985. Calcareous nannofossil biostratigraphy of the Middle America trench and slope, Deep Sea Drilling Project Leg 84. In: von Heune, R., Aubouin, J., et al., Initial Reports DSDP 84, Washington (U.S. Govt. Printing Office), 339-361. doi:10.2973/dsdp.proc.84. 108.1985

Findlay, C. S., Flores, J. A., 2000. Subtropical front fluctuations south of Australia $\left(45^{\circ} 09^{\prime} \mathrm{S}, 146^{\circ} 17^{\prime} \mathrm{E}\right)$ for the last 130 ka years based on calcareous nannoplankton. Marine Micropaleontology 40, 403-416.

Flower, B.P., Zachos, J.C., Paul, H., 1997. Milankovitchscale climate variability recorded near the Oligocene/ Miocene boundary. In: Curry, W.B., Shackleton, N.J.,
Richter, C., et al., Proceedings ODP, Initial Reports 154 (Ocean Drilling Program, College Station, TX), 433439. doi:10.2973/odp.proc.sr.154.141.1997

Fornaciari, E., 1996. Biocronologia a nannofossili calcarei e stratigrafia ad eventi nel Miocene Italiano. Unpublished Ph. D. Thesis, Università degli studi di Padova, Padova.

Fornaciari, E., Raffi, I., Rio, D., Villa, G., Backman, J., Olafsson, G., 1990. Quantitative distribution patterns of Oligocene and Miocene calcareous nannofossils from the western equatorial Indian Ocean.). In: Duncan, R.A., Backman, J., Peterson, L.C., et al., Proceedings ODP, Scientific Results 115 (Ocean Drilling Program, College Station, TX), 237-254. doi:10.2973/odp.proc.sr.115.153. 1990

Fornaciari, E., Backman, J., Rio, D., 1993. Quantitative distribution patterns of selected lower to middle Miocene calcareous nannofossils from the Ontong Java Plateau. In: Berger, W.H., Kroenke, L. W., Janecek, T.R., et al., Proceedings ODP, Scientific Results 130 (Ocean Drilling Program, College Station, TX), 245-258. doi:10.2973/ odp.proc.sr.130.009.1993

Fornaciari, E., Rio, D., 1996. Latest Oligocene to early middle Miocene quantitative calcareous nannofossil biostratigraphy in the Mediterranean region. Micropaleontology 42,1-36.

Fornaciari, E., Di Stefano A., Rio, D., Negri, A., 1996. Middle Miocene quantitative calcareous nannofossil biostratigraphy in the Mediterranean region. Micropaleontology 42, 37-63.

Fornaciari, E., Agnini, C., Catanzariti, R., Rio, D., Bolla, E.M., Valvasoni, E., 2010. Mid-latitude calcareous nannofossil biostratigraphy and biochronology across the middle to late Eocene transition. Stratigraphy 7, 229264.

Gartner, S., 1969. Correlation of Neogene planktonic foraminifer and calcareous nannofossil zones. Transactions of the Gulf Coast Association of Geological Societies 19, 585-599.

Gartner, S., 1971. Calcareous nannofossils from the JOIDES Blake Plateau cores and revision of Paleogene nannofossil zonation. Tulane Stud. Geol. 8, 101-121.

Gartner, S., 1977. Calcareous nannofossil biostratigraphy and revised zonation of the Pleistocene. Marine Micropaleontology 2, 1-25.

Gartner, S., 1992. Miocene nannofossil chronology in the North Atlantic, DSDP Site 608. Marine Micropaleontology 18, 307-331.

Gartner, S., Bukry, D., 1975. Morphology and phylogeny of the coccolithophycean family Ceratolithaceae. Journal of Research of the U.S. Geological Survey 3, 451-465.

Gibbs, S. J., Young, J. R., Bralower, T.J., Shackleton, N.J., 2005. Nannofossil evolutionary events in the midPliocene: an assessment of the degree of synchrony in the extinctions of Reticulofenestra pseudoumbilicus and Sphenolithus abies. Palaeogeography, Palaeoclimatology, Palaeoecology 217, 155-172. doi:10.1016/j.palaeo.2004.11.005 
Haq, B. U., 1973. Evolutionary trends in the Cenozoic coccolithophore genus Helicopontosphaera. Micropaleontology 19, 32-52.

Hay, W.W., Mohler, H., Roth, P.H., Schmidt, R.R., Boudreaux, J.E., 1967. Calcareous nannoplankton zonation of the Cenozoic of the Gulf Coast and CaribbeanAntillean area, and transoceanic correlation. Transactions of the Gulf Coast Association of Geological Societies 17, 428-480.

Hay, W. W., Beaudry, F. M., 1973. Calcareous nannofossils Leg 15, Deep Sea Drilling Project. In: Edgar, N. T., Saunders, J.B., et al., Initial Reports DSDP 15, Washington (U.S. Govt. Printing Office), 625-683. doi:10.2973/ dsdp.proc.15.115.1973

Hilgen, F. J., Abdul Aziz, H., Krijgsman, W., Raffi, I., Turco, E., 2003. Integrated stratigraphy and astronomical tuning of the Serravallian and lower Tortonian at Monte dei Corvi (middle upper Miocene, northern Italy). Palaeogeograpy, Palaeoclimatology, Palaeoecology 199, 299264. doi:10.1016/S0031-0182(03)00505-4

Jordan, R. W., Shao, M., Eglinton, G., Weaver, P.P. E., 1996. Coccolith and alkenone stratigraphy at a NW Africa upwelling site (ODP658C) over the last 130,000 years. In: Moguilevsky, A., Whatley, R. (Eds.), Microfossils and oceanic environments. University of Wales Aberystwyth Press, 111-130.

Krijgsman, W., Hilgen, F., Raffi, I., Sierro, F., Wilson, D., 1999. Chronology, causes and progression of the Messinian salinity crisis. Nature 400, 652-655.

Lisiecki, L.E., Raymo, M.E., 2005. A Plio-Pleistocene stack of 57 globally distributed benthic d180 records. Paleoceanography 20, PA1003. doi:10.1029/2004PA001 071

Lourens, L.J., Hilgen, F.J., Shackleton, N.J., Laskar, J., Wilson, D., 2004. The Neogene Period. In: Gradstein, F. M., Ogg, J. G., Smith, A. G. (Eds.), A Geological Time Scale 2004. Cambridge University Press, Cambridge, 409-440

Martini, E., 1969. Nannoplankt aus dem Latdorf (locus typicus) und weltweite Parallelisierungen im oberen Eozän und unteren Oligozän. Senckenberg Lethaea 50, 117-159.

Martini, E., 1970. Standard Palaeogene calcareous nannoplankton zonation. Nature 226, 560-561.

Martini, E., 1971. Standard Tertiary and Quaternary calcareous nannoplankton zonation. In: Farinacci, A. (Ed.), Proceedings 2nd International Conference Planktonic Microfossils Roma: Rome (Ed. Tecnosci.) 2, 739-785.

Martini,E., Worsley, E., 1970. Standard Neogene calcareous nannoplankton zonation. Nature 225, 289-290.

Martini, E., Worsley, T., 1971. Tertiary calcareous nannoplankton from the western Equatorial Pacific. In: Winterer, E.L., Riedel, W.R., et al., Initial Reports DSDP 7, Washington (U.S. Govt. Printing Office), 1471-1507. doi:10.2973/dsdp.proc.7.129.1971

Moshkovitz, S., Ehrlich, A., 1980. Distribution of the calcareous nannofossils in the Neogene sequence of the Jaffa-1 Borehole, Central Coastal Plain. Geological Survey Israel Report PD/1/80, 1-25.
Okada, H., Bukry, D., 1980. Supplementary modification and introduction of code numbers to the low-latitude coccolith biostratigraphic zonation (Bukry 1973, 1975). Marine Micropaleontology 5, 321-325.

Perch-Nielsen, K., 1985. Cenozoic calcareous nannofossils. In: Bolli, H.M., Saunders, J.B., Perch-Nielsen, K., (Eds.), Plankton Stratigraphy, Cambridge University Press, Cambridge, 427-554.

Pälike, H., Moore, T., Backman, J., Raffi, I., Lanci, L., Parés, J.M., Janecek, T., 2005. Integrated stratigraphic correlation and improved composite depth scales for ODP Sites 1218 and 1219. In: Wilson, P.A., Lyle, M., Firth, J.V., et al., Proceedings ODP, Scientific Results 199 (Ocean Drilling Program, College Station, TX), 142. doi:10.2973/odp.proc.sr.199.213.2005

Pälike, H., Norris, R. D., Herrle, J. O., Wilson, P. A., Coxall, H. K., Lear, C.H., Shackleton, N.J., Tripati, A. K., Wade, B.S., 2006. The heartbeat of the Oligocene climate system. Science 314, 1894-1898. doi:10.1126/science.1133822

Pälike, H., et al., 2007. Ceara Rise Oligocene-Miocene ODP926B Stable Isotope Data. IGBP PAGES/World Data Center for Paleoclimatology. Data Contribution Series \# 2007-017 NOAA/NCDC Paleoclimatology Program, Boulder CO, USA.

Raffi, I., 1999. Precision and accuracy of nannofossil biostratigraphic correlation. Philosophical Transactions of the Royal Society of London, Series A: Mathematical Physics and Science 357, 1975-1993.

Raffi, I., 2002. Revision of the early-middle Pleistocene calcareous nannofossil biochronology (1.75-0.85 Ma). Marine Micropaleontology 45, 25-55.

Raffi, I., Backman, J., Rio, D., Shackleton, N. J., 1993. PlioPleistocene nannofossil biostratigraphy and calibration to oxygen isotope stratigraphies from Deep Sea Drilling Project Site 607 and Ocean Drilling Program Site 677. Paleoceanography 8, 387-408.

Raffi, I., Flores, J.A., 1995. Pleistocene through Miocene calcareous nannofossils from Eastern Equatorial Pacific Ocean (Leg 138). In: Pisias, N. G., Mayer, L. A., Janecek, T.R., Palmer-Julson, A., van Andel, T.H., et al., Proceedings ODP, Scientific Results 138 (Ocean Drilling Program, College Station, TX), 233-286. doi:10.2973/ odp.proc.sr.138.112.1995

Raffi, I, Rio, D., d'Atri, A., Fornaciari, E., Rocchetti, S., 1995. Quantitative distribution patterns and biomagnetostratigraphy of middle and late Miocene calcareous nannofossils from equatorial Indian and Pacific oceans (Legs 115, 130, and 138). In: Pisias, N.G., Mayer, L. A., Janecek, T.R., Palmer-Julson, A., van Andel, T.H., et al., Proceedings ODP, Scientific Results 138 (Ocean Drilling Program, College Station, TX), 479-502. doi:10.2973/ odp.proc.sr.138.125.1995

Raffi, I., Backman, J., Rio, D., 1998. Evolutionary trends of calcareous nannofossils in the late Neogene. Marine Micropaleontology 35, 17-41.

Raffi, I., Backman, J., Fornaciari, E., Pälike, H., Rio, D., Lourens, L., Hilgen, F., 2006. A review of calcareous nannofossil astrobiochronology encompassing the past 
25 million years. Quaternary Science Reviews 25, 31133137. doi:10.1016/j.quascirev.2006.07.007

Raymo, M.E., Ruddiman, W.F., Backman, J., Clement, B.M., Martinson, D.G., 1989. Late Pliocene variation in northern hemisphere ice sheets and North Atlantic deep circulation. Paleoceanography 4, 413-446.

Rio., D., 1974. Remarks on late Pliocene - early Pleistocene calcareous nannofossil stratigraphy in Italy. L'Ateneo Parmense. Acta Naturalia 10, 409-449.

Rio, D., 1982. The fossil distribution of coccolithophore genus Gephyrocapsa Kamptner and related Plio-Pleistocene chronostratigraphic problems. In: Prell, W.L., Gardner, J. V., et al., Initial Reports DSDP 68, Washington (U.S. Govt. Printing Office), 325-343. doi:10.2973/ dsdp.proc.68.109.1982

Rio, D., Sprovieri, R., Raffi, I., 1984. Calcareous plankton stratigraphy and biochronology of the Pliocene-lower Pleistocene succession of the Capo Rossello area, Sicily. Marine Micropaleontology 9, 135-180.

Rio, D., Raffi, I., Villa, G., 1990a. Pliocene-Pleistocene calcareous nannofossil distribution patterns in the western Mediterranean. In: Kastens, K. A., Mascle, J., et al., Proceedings ODP, Scientific Results 107 (Ocean Drilling Program, College Station, TX), 513-533. doi:10.2973/ odp.proc.sr.107.164.1990

Rio, D., Fornaciari, E., Raffi, I., 1990b. Late Oligocene through early Pleistoene calcareous nannofossils from western equatorial Indian Ocean (Leg 115). In: Duncan, R.A., Backman, J., Peterson, L.C., et al., Proceedings ODP, Scientific Results 115 (Ocean Drilling Program, College Station, TX), 175-235. doi:10.2973/odp.proc.sr. 115.152 .1990

Roth, P.H., Baumann, P., Bertolino, V., 1971. Late EoceneOligocene calcareous nannoplankton from central and northern Italy. In: Farinacci, A. (Ed.), Proceedings 2nd International Conference Planktonic Microfossils Roma: Rome (Ed. Tecnosci.) 2, 1069-1097.

Schneider, D.A., 1995. Paleomagnetism of some Leg 138 sediments: Detailing Miocene magnetostratigraphy. In: Pisias, N. G., Mayer, L. A., Janecek, T. R., Palmer-Julson, A., van Andel, T.H., et al., Proceedings ODP, Scientific Results 138 (Ocean Drilling Program, College Station, TX), 69-72. doi:10.2973/odp.proc.sr.138.105.1995

Shackleton, N. J., Baldauf, J., Flores, J. A., Iwai, M., Moore, T.C., Raffi, I., Vincent, E., 1995. Biostratigraphic summary for Leg 138. In Pisias, N. G., Mayer, L. A., Janecek, T.R., Palmer-Julson, A., van Andel, T. H., et al., Proceedings ODP, Scientific Results 138 (Ocean Drilling Program, College Station, TX), 517-536. doi:10.2973/ odp.proc.sr.138.127.1995

Shackleton, N.J., Crowhurst, S., 1997. Sediment fluxes based on an orbitally tuned time scale $5 \mathrm{Ma}$ to $14 \mathrm{Ma}$, Site 926. In: Curry, W.B., Shackleton, N.J., Richter, C., Bralower, T.J., et al., Proceedings ODP, Scientific Re- sults 154 (Ocean Drilling Program, College Station, TX), 69-82. doi:10.2973/odp.proc.sr.154.102.1997

Shackleton, N. J., Hall, M. A., Raffi, I., Tauxe, L., Zachos, J., 2000. Astronomical calibration age for the OligoceneMiocene boundary. Geology 28, 447-450. doi:10.1130/ 0091-7613(2000)28<447:ACAFTO>2.0.CO;2

Takayama, T., 1993. Notes on Neogene calcareous nannofossil biostratigraphy of the Ontong Java Plateau and size variations of Reticulofenestra coccoliths. In: Berger, W.H., Kroenke, L. W., Mayer, L. A., et al., Proceedings ODP, Scientific Results 130 (Ocean Drilling Program, College Station, TX), 179-229. doi:10.2973/odp.proc. sr.130.020.1993

Theodoridis, S., 1984. Calcareous nannofossil biozonation of the Miocene and revision of the helicoliths and discoasters. Utrecht Micropaleontological Bulletins 32, 1-271.

Thierstein, H. R., Geitzenauer, K. R., Molfino, B., Shackleton, N.J., 1977. Global synchroneity of late Quaternary coccolith datum levels: validation by oxygen isotopes. Geology 5, 400-404.

Vergnaud Grazzini, C., Saliège, J.F., Urrutiaguer, M. J., Iannace, A., 1990. Oxygen and carbon isotope stratigraphy of ODP Hole 653A and Site 654: The Pliocene-Pleistocene glacial history recorded in the Tyrrhenian Basin (west Mediterranean). In: Kastens, K.A., Mascle., J., et al., Proceedings ODP, Scientific Results 107 (Ocean Drilling Program, College Station, TX), 361-386. doi:10.2973/odp.proc.sr.107.153.1990

Villaneuva, J., Flores, J. A., Grimalt, J.O., 2002. A detailed comparison of the Uk' 37 and coccolith records over the past 290 kyears: implications to the alkenone paleotemperature method. Organic Geochemistry 33, 897-905.

Wade, B.S., Pearson, P.N., Berggren, W.A., Pälike, H., 2011. Review and revision of Cenozoic tropical planktonic foraminiferal biostratigraphy and calibration to the geomagnetic polarity and astronomical time scale. Earth-Science Reviews 104, 111-142. doi:10.1016/ j.earscirev.2010.09.00

Wei, W., 1993. Calibration of upper Pliocene-lower Pleistocene nannofossil events with oxygen isotope stratigraphy. Paleoceanography 8, 85-99.

Winterer, E.L., Riedel, W.R., et al., 1971. Initial Reports DSDP 7, Washington (U.S. Govt. Printing Office), 11757. doi:10.2973/dsdp.proc.7.1971

Young, J., 1990. Size variation of Neogene Reticulofenestra coccoliths in Indian Ocean DSDP cores. Journal of Micropalaeontology 9, 71-86.

Zachos, J. C., Kroon, D., Blum, P., et al., 2004. Proceedings ODP, Initital Reports 208, College Station, TX (Ocean Drilling Program). doi:10.2973/odp.proc.ir.208.2004

Manuscript received: March 28, 2012; rev. version accepted: June 4, 2012. 